\title{
Fate of Postharvest Woody Debris, Mammal Habitat, and Alternative Management of Forest Residues on Clearcuts: A Synthesis
}

\author{
Thomas P. Sullivan ${ }^{1, *}$, Druscilla S. Sullivan ${ }^{2}$ and Walt Klenner ${ }^{3}$ \\ 1 Department of Forest and Conservation Sciences, Faculty of Forestry, University of British Columbia, \\ 2424 Main Mall, Vancouver, BC V6T 1Z4, Canada \\ 2 Applied Mammal Research Institute, 11010 Mitchell Avenue, Summerland, BC V0H 1Z8, Canada; \\ dru.sullivan@appliedmammal.com \\ 3 Ministry of Forests, Lands, and Natural Resource Operations, 441 Columbia Street, \\ Kamloops, BC V2C 2T7, Canada; walt.klenner@gov.bc.ca \\ * Correspondence: tom.sullivan@ubc.ca
}

check for updates

Citation: Sullivan, T.P.; Sullivan, D.S.; Klenner, W. Fate of Postharvest Woody Debris, Mammal Habitat, and Alternative Management of Forest Residues on Clearcuts: A Synthesis. Forests 2021, 12, 551. https:// doi.org/10.3390/f12050551

Academic Editor: Timothy A. Martin

Received: 29 January 2021

Accepted: 25 April 2021

Published: 28 April 2021

Publisher's Note: MDPI stays neutral with regard to jurisdictional claims in published maps and institutional affiliations.

Copyright: (c) 2021 by the authors. Licensee MDPI, Basel, Switzerland. This article is an open access article distributed under the terms and conditions of the Creative Commons Attribution (CC BY) license (https:// creativecommons.org/licenses/by/ $4.0 /)$.

\begin{abstract}
Coarse woody debris on the forest floor contributes to maintenance of forest biodiversity and long-term ecosystem productivity. Down wood is often dispersed over harvested sites during logging activities, thereby leaving piles of postharvest debris as "excess" material at landings and roadsides. These wood residues may be burned in most jurisdictions in North America to reduce a perceived fire hazard. The fire hazard debate needs to acknowledge the documented benefits of woody debris retention while striking a balance among biodiversity, bioenergy, and alternative uses for debris, while reducing ignitions by humans. The burning of excess woody debris also creates smoke, causes the release of greenhouse gas (GHG) emissions, and creates human health issues, particularly for vulnerable individuals. The relationship of wildfire smoke to human health problems is well documented. However, there is no scientific evidence showing that postharvest debris piles are ignition points for forest fires, other than those caused by humans. Wood residues from forest harvesting or natural disturbance wood from wildfire and insect outbreaks may be used as renewable biomass "feedstocks" that could help improve energy supplies and reduce GHG emissions. If not marketable, the management of postharvest debris should seek alternative outlets that do not dispose of debris by burning, but still meet fire hazard abatement requirements. The construction of woody debris structures (e.g., piles and windrows) built at the time of forest harvesting and log processing, or later at the site preparation stages, has positive benefits for wildlife habitat and forest biodiversity. A windrow or series of piles may connect patches and reserves of mature forest and riparian areas on clearcut openings. Piles and windrows have consistently provided habitat on new clearcuts for southern red-backed voles (Myodes gapperi) and Microtus voles, as well as a host of other forest-floor small mammal species, at least up to 12 years postconstruction. Woody debris provides important habitat for foraging and cover attributes for marten (Martes americana), weasels (Mustela spp.), and other furbearers. A list of "What to do?" and "When and Where?" with options for construction of woody debris habitats: poorest, good, better, and best are given. In the cases where fire risk from humans is minimized and there are no marketable wood products, eight alternative management scenarios for postharvest woody debris are provided. These include: (1) piles for wildlife habitat; (2) distribution of debris in partial cut forests; (3) machinery to break up and crush debris; (4) protection of riparian zones with barriers for cattle; (5) construction of range fencing; (6) reclamation of landings and skid-trails; (7) soil fertility and reduction in weed competition and drought for planted conifers; and (8) slope stabilization and revegetation. Advantages and disadvantages (if known) are given for each alternative. A flow chart for the fate of excess postharvest woody debris with respect to fire hazard abatement and markets or nonmarkets is given.
\end{abstract}

Keywords: alternative management; biodiversity; fire hazard abatement; forest residues; mammal habitat; piles and windrows; smoke emissions; woody debris 


\section{Introduction}

\subsection{The Problem}

Woody debris in the coniferous and deciduous forests of temperate and boreal ecological zones is created by natural and harvesting (primarily logging) disturbances. Natural disturbances include wildfire, insect outbreaks, windthrow, and drought, which seem to be increasing in frequency and severity in recent decades [1-4]. The clearcutting of forests, with and without some form of green-tree retention, remains the dominant silvicultural system in much of North America and northern Europe [5,6]. Depending on the forest type, clearcutting may generate much woody debris from the processing of felled trees into transportable logs, leaving behind tops, bole ends, branches, and low-quality commercial trees. The harvesting of salvage wood from natural disturbances also adds to a buildup of woody debris [7]. Coarse woody debris (CWD) (dead or down wood) plays a major role in ecosystem function and is essential to the maintenance of forest biodiversity and long-term site productivity. These functions include nutrient cycling, the contribution of organic matter to soil structure, and modification of the microclimate [8-10]. Down wood is often dispersed over harvested sites during the logging operation, thereby leaving piles of postharvest debris as "excess" material at landings and roadsides. In addition, future recruitment of woody debris in managed forests must be continually planned for in successive rotations. However, excess woody debris is often perceived as "wood waste," particularly the residue (slash) occurring after conventional and salvage harvesting of forests $[7,11]$. If piles or accumulations of excess woody debris are considered a fire-fuel hazard, then current forest management policy requires forest operators to dispose of this material as a means of hazard abatement in most provinces in Canada and in many jurisdictions in the United States (US). These wood residues are typically burned to reduce a perceived fire hazard. However, this practice creates much smoke that exacerbates the release of greenhouse gas (GHG) emissions and may also create a potential human health concern in nearby communities [12]. Wood residues may be used as renewable biomass feedstocks, such as pellet production for European markets, that could help improve energy supplies and reduce GHG emissions [13-15].

The retention of some postharvest woody debris on newly harvested forest sites may provide critical habitat for wildlife and biodiversity [16-18]. This practice is particularly relevant on clearcut openings where many mammal species have declined in abundance or disappeared [19]. Furbearers such as the American marten (Martes americana), in particular, and various small weasels (Mustela spp.) are negatively affected by the large openings created by clearcutting [20-22]. A major prey species for small mustelids is the southern red-backed vole (Myodes gapperi) that occupies old forests and disappears for many decades after clearcutting, particularly in western North America [23,24]. A recent meta-analysis on the effects of harvesting forest-based biomass on terrestrial wildlife concluded that there were no consistent negative effects on biodiversity [25]. However, there have been relatively few experimental studies on the management of woody debris as restoration structures for mammals in harvested forest ecosystems [26]. A major exception has been the construction of woody debris structures (e.g., piles and windrows) built at the time of forest harvesting and log processing, or later at the site preparation stages. This practice has generated some vital mammalian biodiversity networks for small mustelids, small mammal prey species, and other mammalian carnivores [27-29].

The current forest management system of disposing of excess postharvest woody debris by burning is exacerbating climate change and concurrently removing biomass for bioenergy production and potential habitat for mammals and other wildlife, thereby compromising our attempts to conserve biodiversity in managed forests. Thus, this paper provides a review and synthesis, primarily for North America and Europe, of the following topics: (1) the actual wildfire hazard associated with debris piles; (2) the impact on human health of burning debris; (3) the potential value of woody debris for bioenergy; (4) the efficacy of constructed woody debris structures for mammal habitat; and (5) alternative management possibilities for woody debris to abate a potential fuel hazard. 


\subsection{Database}

The following electronic databases were searched for the period 1990 to 2020: specific journals including Forest Ecology and Management, Canadian Journal of Forest Research, Scandinavian Journal of Forest Research, and Google Scholar and Summon 2.0 search engines across a range of journals publishing papers in English. Additional studies were identified from reference lists of individual publications and from review papers.

\section{Debris Piles and Wildfire Hazard}

In terms of perceived fire hazard, there is no scientific evidence showing that postharvest debris piles are ignition points for forest fires, other than those caused by humans. Lightning strikes and human-caused fires make up the majority of ignitions in British Columbia (BC), Canada [30,31]. Human-initiated fires could be minimized by operations such as road deactivation, and/or reduction of fuel load in areas most frequented by humans. Areas of lightning ignition are partially predictable by weather patterns and history. The relationship of lightning strikes and debris piles has been surveyed in Alberta, Canada, which receives high numbers of lightning strikes each year. However, there was no pattern in terms of pile location, either in the cutblock (e.g., unit of forest stand harvested by clearcutting) or on the landscape as a whole. A major assumption was that piles struck by lightning would be located beside a stand or on a hilltop, but evidence showed the location of these pile fires was random [32].

It is generally agreed that fuel reduction treatments reduce forest wildfire severity [33], but how much area needs to be treated is less clear, with fuel type and arrangement being important factors [34]. Studies on fuel reduction revolve around forested areas where there has been a recent fire, insect outbreak, or a windthrow event. These are quite different environments than clearcuts where there are often, few, if any, standing live or dead trees. However, in jurisdictions where retained green trees and snags are required, there are often patches or scattered trees in clearcuts. Ref. [35] found that fuel moisture levels can override the influence of fuel spatial arrangement with very moist fuel being less vulnerable to fire than its load would predict. This concept of fuel moisture and climate being a significant attribute in fire hazard is also discussed by [36]. Where habitats regularly have dehydrating weather conditions, such as ponderosa pine (Pinus ponderosa) and interior Douglas-fir (Pseudotsuga menziesii var. glauca) forests, then fuel type, quantity, and arrangement become more influential in the fire regime than in areas with cool, moist weather systems. On the assumption that some clearcuts occur in dry ecosystems, the retention of higher levels of debris in piles/windrows may be best suited to wetter habitats, elevations, and landscapes.

Large woody fuels ( $>7.5 \mathrm{~cm}$ diameter) have relatively low fire risk [37] and do not affect the spread or ignition potential of a fire but can influence the size and severity of a fire [38]. Loading, size, and decay state of large woody debris are variables that affect fire persistence, with pieces $>25.4 \mathrm{~cm}$ being less of a hazard [38]. Larger, more decayed wood will smolder for longer periods of time, but the potential increased risk for spotting and crown fires which this invokes on a forest floor would not pertain to a clearcut environment. Larger pieces of downed wood have the advantage of longevity for wildlife and soil productivity [38]. In addition, compacted fuels are less likely to ignite or burn vigorously $[39,40]$, thereby suggesting that mulching or compacted windrows and/or piles of debris could possibly be left on-site without fire hazard. Recent Australian research, using laboratory wind tunnels, reported that the rate of spread of fire was halved among small-diameter $(0.6-5.0 \mathrm{~cm})$ twigs and branches [41]. Clearly, additional research is required to fully understand the role of various sizes of woody debris in assisting or retarding the spread of wildfire, but it does appear that larger diameter downed wood does not increase the rate of fire spread.

\section{Wildfire Smoke and Human Health}

The fire hazard issue needs to acknowledge the documented benefits of woody debris retention while striking a balance among biodiversity, bioenergy, and alternative uses 
to dispose of excess debris, while reducing ignitions by humans. The burning of excess woody debris creates much smoke that exacerbates the release of greenhouse gas (GHG) emissions and may also create a potential human health concern in nearby communities (see Figures 1 and 2). The relationship of wildfire smoke to human health problems is well documented, and the smoke arising from the burning of debris piles is not likely a different issue [12]. A review paper analyzing 61 epidemiological studies on the human health risks of wildfires concluded that, during or after a wildfire, the levels of coarse dust particles 2.5 to 10 micrometres $\left(\mathrm{PM}_{10}\right)$ were 1.2-10 times higher than prior to burning [12]. The level of particulate matter is the most commonly used marker for wildfire smoke. Particles of this size range are able to enter the respiratory system with the potential of health risks. The majority of studies analyzed in the paper [12] confirmed the increased risk of respiratory and cardiovascular diseases resulting from contact with wildfire smoke. A more recent publication reports that there is a positive association between wildfire smoke $\left(\mathrm{PM}_{2.5}\right)$ and respiratory health but cardiovascular studies remain inconclusive [42]. Children, the elderly, and individuals with chronic diseases are the most vulnerable. Respiratory effects include hospitalization, use of respiratory medication, coughing, wheezing, and especially increased asthma issues. Hypertensive disorders, eye irritation, pregnancy outcomes [43], bone marrow responses, and nonrespiratory atopic disease were other consequences noted in various related studies [12].

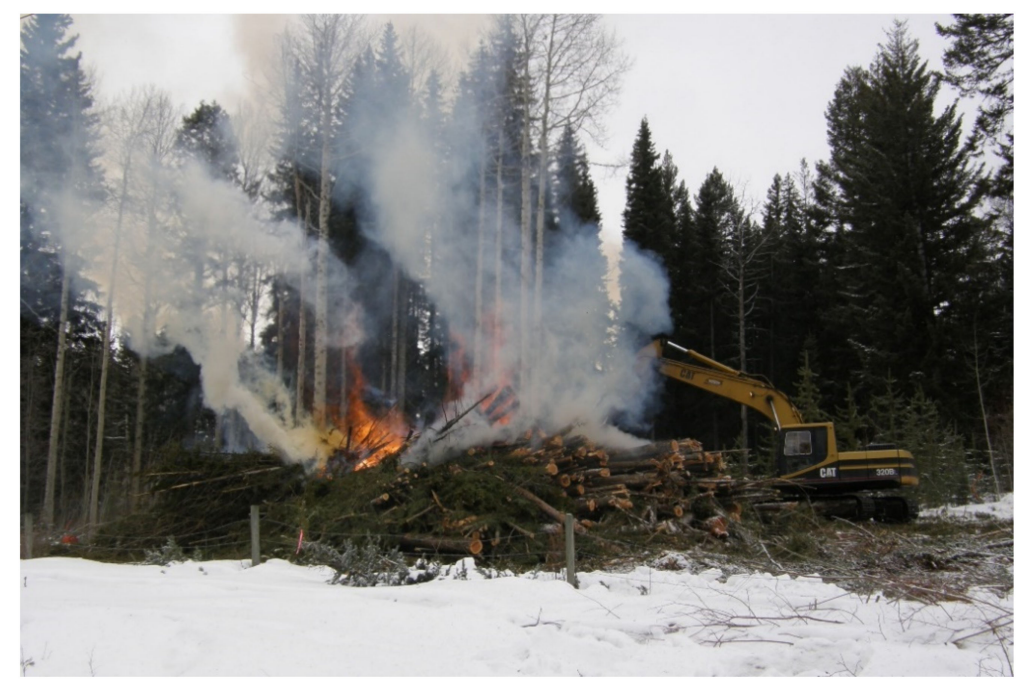

Figure 1. Burning of debris pile.

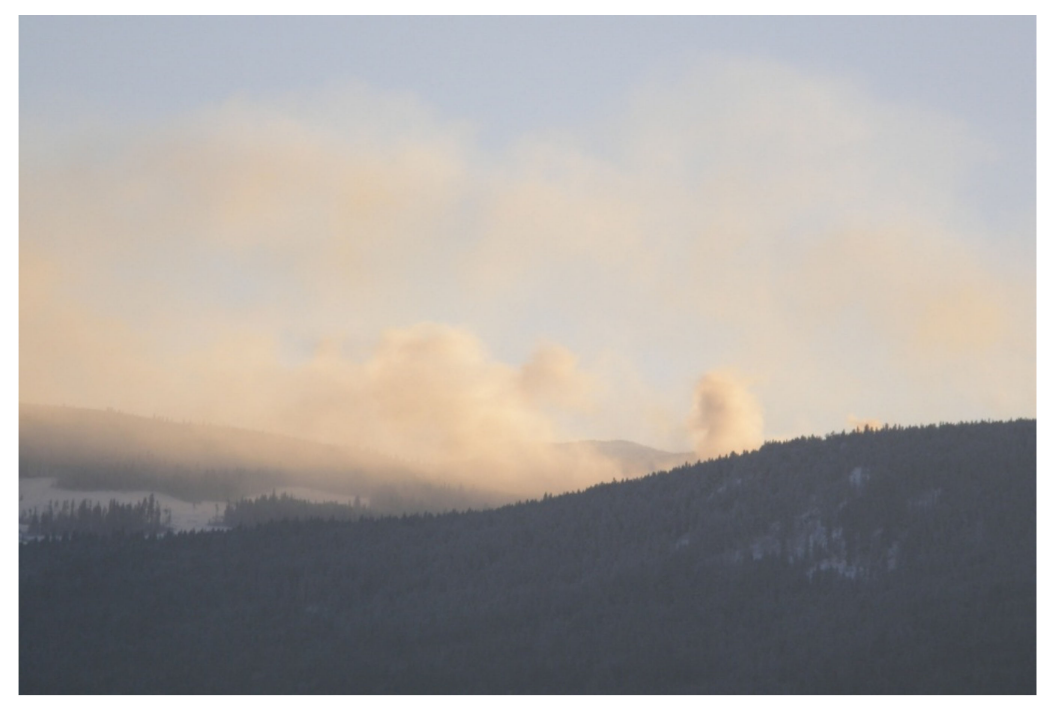

Figure 2. Smoke from burning of debris piles. 
The distinctive chemical properties of forest fire smoke and their high levels during a fire may also play a part in health risk. During wildfire periods, levels of carbon monoxide can increase $30-40 \%[44,45]$ with wildfire smoke having elevated black carbon levels [46] and containing polycyclic aromatic hydrocarbon levels 15 times higher than background levels [47]. Ref. [48] provides a table listing the health-damaging pollutants resulting from the burning of wood products. This table includes carbon monoxide, ozone, nitrous oxide, hundreds of hydrocarbons and oxygenated organics, chlorinated organics, free radicals, and particulate matter.

\section{Woody Debris as Biomass and Potential Wood Products}

Wood residues from forest harvesting or disturbance wood from wildfire and insect outbreaks may be used as renewable biomass "feedstocks" that could help improve energy supplies and reduce GHG emissions in North American and European forestry sectors [13-15,49,50]. The production of biofuels (e.g., wood pellets) from sawmill wood residues and postharvest debris is a major bioenergy endeavour across Canada and the southeastern US supplying European and other countries [15,51-53]. However, the interplay between volume, transportation distance, plant capacity, and energy price shape whether removal or retention is the appropriate option. For example, remote harvesting sites with low debris volumes feeding a small-capacity facility offer little economic benefit [27]. In these latter cases, the management of postharvest debris should seek alternative outlets that do not dispose of debris by burning, but still meet fire hazard abatement requirements. Fibre from postharvest debris piles could also support the manufacturing of wood products (e.g., post and rail, cants, and other nonstandard dimensional wood products) that could generate direct and indirect employment and revenues.

\section{Woody Debris Structures as Mammal Habitat}

In two comprehensive meta-analyses of the relationships between biomass removal and biodiversity, $[15,25]$ concluded that the effects of CWD manipulations on mammals were mixed. The first analysis focused on CWD removals and there seemed to be no strong experimental evidence to suggest that abundance or diversity of mammals would be affected by removal of forest residues [25]. However, the second analysis found negative responses of two genera of shrews (Blarina and Sorex spp.) and cotton rats (Sigmodon hispidus) to loss of habitat and cover [15]. In general, neither of these meta-analyses found consistent negative effects of harvesting woody biomass on biodiversity $[15,25]$.

In our updated summary of studies (forest-floor small mammals and small mustelids) with construction of postharvest woody debris structures there was a clear pattern of significant positive responses (9 of 19) of the major species to large-scale (e.g., $2 \mathrm{~m}$ by $5-7 \mathrm{~m}$ ) habitats of piles and windrows of woody debris (Table 1). This outcome likely reflected the variety of manipulations of CWD noted in our analysis or naturally occurring amounts on the forest floor [18]. 


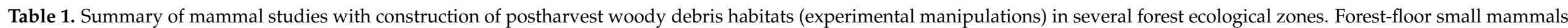

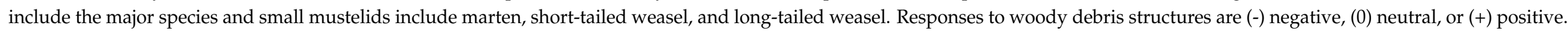

\begin{tabular}{|c|c|c|c|c|c|c|c|c|c|}
\hline Location & Forest Type & Woody Debris & Season & Years + Reps & Small Mammal Abundance & SR & SD & Small Mustelids & Study \\
\hline Alberta & Boreal mixedwood & Swaths & Summer & $4+2$ & $\begin{array}{l}\text { RBV (0) } \\
\operatorname{DM}(0)\end{array}$ & & & & {$[54]$} \\
\hline Alberta & Boreal mixedwood & Piles & Summer & $1+1$ & $\begin{array}{l}\operatorname{RBV}(+) \\
\operatorname{DM}(0)\end{array}$ & & & Weasel (+) & [55] \\
\hline B.C. & IDF Spruce-fir & Swaths & Summer & $4+3$ & $\mathrm{DM}(0)$ & & & & {$[56]$} \\
\hline Oregon & Douglas-fir & Small piles & Summer & $1+3$ & $\begin{array}{l}\text { WRBV (0) } \\
\text { DM (0) }\end{array}$ & & & & [57] \\
\hline South Carolina & Loblolly pine & Swaths & $\begin{array}{l}\text { Spring, Summer } \\
\text { Winter }\end{array}$ & $3+3$ & $\begin{array}{l}\text { BLA (0) } \\
\text { SOR (0) } \\
\text { CRY (0) }\end{array}$ & & & & {$[58]$} \\
\hline South Carolina & Loblolly pine & Swaths & All seasons & $2+3$ & $\begin{array}{l}\text { BLA (+) } \\
\text { SOR (+) } \\
\text { CRY }(0)\end{array}$ & & & & [59] \\
\hline Quebec & Boreal black spruce & Small piles & Summer & $2+4$ & $\begin{array}{l}\operatorname{RBV}(+) \\
\operatorname{DM}(+)\end{array}$ & & & & {$[60]$} \\
\hline B.C. & $\begin{array}{c}\text { Montane Spruce } \\
\text { IDF }\end{array}$ & $\begin{array}{l}\text { Piles and } \\
\text { windrows }\end{array}$ & Summer & $3+3$ & $\operatorname{LTV}(+)$ & & & Weasel (+) & {$[61]$} \\
\hline B.C. & $\begin{array}{l}\text { Montane Spruce } \\
\text { ICH IDF }\end{array}$ & $\begin{array}{c}\text { Windrows and } \\
\text { GTR }\end{array}$ & Summer & $3+3$ & $\begin{array}{l}\text { RBV (+) } \\
\text { Total (+) }\end{array}$ & $(0)$ & $(0)$ & & [62] \\
\hline B.C. & Spruce-fir ESSF & Swaths & Summer & $4+3$ & RBV (0) & & & & {$[63]$} \\
\hline B.C. & IDF Spruce-fir & Swaths & Summer & $4+3$ & $\begin{array}{l}\operatorname{LTV}(0) \\
\operatorname{MV}(0)\end{array}$ & & & & {$[64]$} \\
\hline $\begin{array}{c}\text { North Carolina + } \\
\text { Georgia }\end{array}$ & Loblolly pine & Piles & Summer & $3 / 4+8$ & $\begin{array}{l}\text { BLA (0) } \\
\text { SOR (0) } \\
\text { CRY (0) }\end{array}$ & & & & {$[65]$} \\
\hline
\end{tabular}


Table 1. Cont

\begin{tabular}{|c|c|c|c|c|c|c|c|c|c|}
\hline Pennsylvania & Hardwoods & Small piles & Summer & $2+6,7$ & $\begin{array}{c}\text { Pero (0) } \\
\text { BREV (0) } \\
\text { NEO (0) }\end{array}$ & & & & [66] \\
\hline $\begin{array}{c}\text { North Carolina }+ \\
\text { Georgia }\end{array}$ & Loblolly pine & Piles & Summer & $3+8$ & $\begin{array}{l}\mathrm{DM}(0) \\
\operatorname{MUS}(0) \\
\text { SIG (0) }\end{array}$ & & & & [67] \\
\hline B.C. & $\begin{array}{c}\text { Montane Spruce } \\
\text { ICH }\end{array}$ & Windrows & Summer & $5+6$ & $\begin{array}{l}\text { Voles }(+) \\
\text { Total }(+)\end{array}$ & $(+)$ & $(+)$ & $\begin{array}{l}\text { Weasel (+) } \\
\text { Marten (+) }\end{array}$ & [29] \\
\hline B.C. & Sub-boreal spruce & $\begin{array}{l}\text { Windrows } \\
\text { (corridors) }\end{array}$ & $\begin{array}{l}\text { Summer and } \\
\text { Winter }\end{array}$ & 2 & $\begin{array}{c}\text { Voles (+) } \\
\text { Mice (+) } \\
\text { Shrews (+) }\end{array}$ & & & Marten (+) & [69] \\
\hline B.C. & $\begin{array}{c}\text { Montane Spruce } \\
\text { IDF }\end{array}$ & $\begin{array}{l}\text { Piles and } \\
\text { windrows }\end{array}$ & Summer & $5,12+3$ & $\begin{array}{l}\text { RBV }(+, 0) \\
\operatorname{LTV}(+, 0) \\
\text { Total }(+, 0)\end{array}$ & $(+, 0)$ & $(0,0)$ & & [70] \\
\hline
\end{tabular}

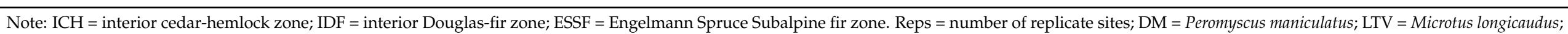

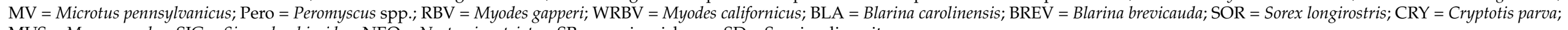
MUS = Mus musculus; $\mathrm{SIG}=$ Sigmodon hispidus; $\mathrm{NEO}=$ Neotamias striatus; $\mathrm{SR}=$ species richness; $\mathrm{SD}=$ Species diversity. 
The major drawbacks appear to be the timing and scale of construction of woody debris habitats. A lack of positive results for abundance of red-backed voles were reported by $[54,57,63]$ where "swaths" or small piles of woody debris were added to sites to a general height of $0.5 \mathrm{~m}$ (Table 1 ). The positive results reported for small piles of debris and red-backed voles by [60] may have been more related to the partially cut stands than structure provided by the debris. An abundance of other small mammal species such as the deer mouse (Peromyscus maniculatus) showed no relationships to CWD in structures on the forest floor [54-57]. However, in sites with natural CWD accumulations from windthrow events, more Peromyscus occurred in debris than control sites [71,72]. Similarly, various chipmunk and shrew species may use CWD as travel paths with little or no population response [72-74]. Clearly, red-backed voles and associated small mammals will persist in these structures for at least 12 years, at or near the abundance levels found in uncut forest [70]. The longevity of the structures may depend on the materials in the piles (e.g., tree species and climate) in terms of decay and functionality. In addition, at least some mammalian carnivores will presumably continue to use these structures for this same period.

In Fennoscandia, forestry is based almost solely on clearcut harvesting and intensive forest management where CWD retention levels are typically $2 \mathrm{~m}^{3} / \mathrm{ha}-6 \mathrm{~m}^{3} / \mathrm{ha}$, which correspond to a few percent of the preharvest volumes [75]. Cover by logs was critical for species richness and overall abundance of forest-floor small mammals in northern Sweden [76]. The bank vole (Myodes glareolus) and gray-sided vole (Myodes rufocanus) are similar species to $M$. gapperi, and both showed a positive correlation to cover of logs in forest habitats [77]. In general, the retention of CWD for the maintenance of small mammal populations and other wildlife on harvested sites is highly recommended in the forests of Fennoscandia and central Europe [78,79]. Thus, there are at least three major species-M. gapperi, M. glareolus, and M. rufocanus - that could potentially be sustained on new clearcuts with a sufficient amount of woody debris. However, other than these references and those from North America, we could find no study results measuring the responses of mammals or other wildlife species to constructed habitats of woody debris in Europe or elsewhere.

\section{Alternative Management of Woody Debris \\ 6.1. Options for Construction of Woody Debris Structures}

Several options for the construction of woody debris habitats are illustrated in Figure 3a-e. The establishment of these habitat networks is site-specific for wherever connectivity among forest reserves and patches is available (Table 2). On sites with substantial debris, these structures may use only $10-15 \%$ of excess postharvest debris, thereby leaving material for other uses such as biofuels and other alternative functions. Piles of postharvest woody debris in a linear configuration already dominate forest harvesting regimes on clearcuts and conservation of this debris provides immediate habitat for various mammal species. Large-scale manipulations of woody debris into piles or windrows are needed to generate unequivocal results in terms of responses in abundance and species richness and diversity of forest-floor small mammals, and sometimes their mustelid predators, as noted in Table 1. Woody debris structures need to be large-scale: at least $2 \mathrm{~m}$ in height and 5-7 $\mathrm{m}$ in width or diameter, arranged as continuous windrows or in a linear array of piles, to provide sufficient habitat for forest-floor small mammals and their predators on clearcuts. A windrow or series of piles should connect patches and reserves of mature forest and riparian areas and allow forest-floor small mammals and some of their predators to access and traverse clearcut openings. For operational and logistical reasons, these structures need to be created at the time of forest harvesting and log processing, or immediately thereafter, to provide sufficient volume of woody material for red-backed voles and other small mammal species before they decline on clearcut sites. 
(a) Poorest option - minimal vertical structure to habitat

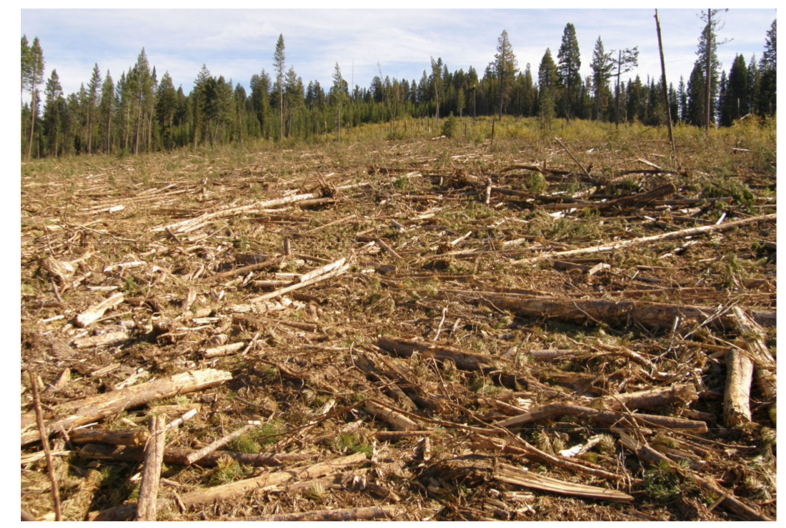

(c) Better option - linear piles

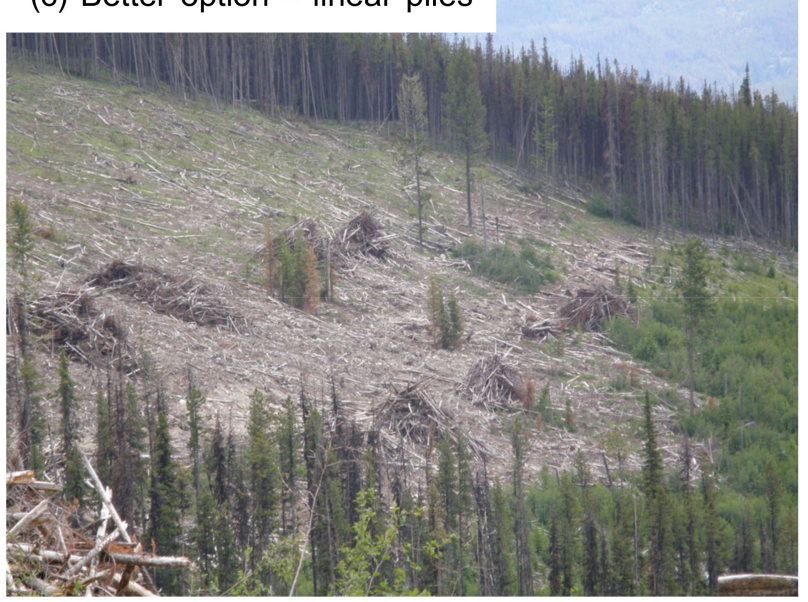

(b) Good option - piles

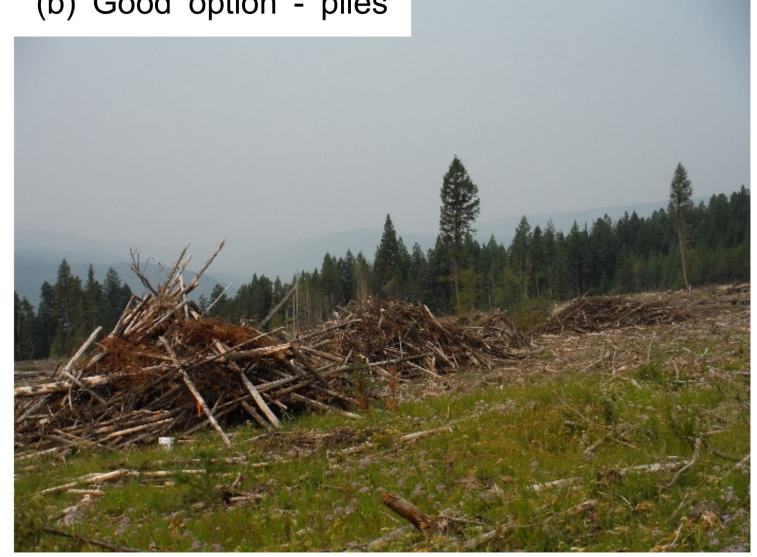

(d) Best option - piles connecting to riparian

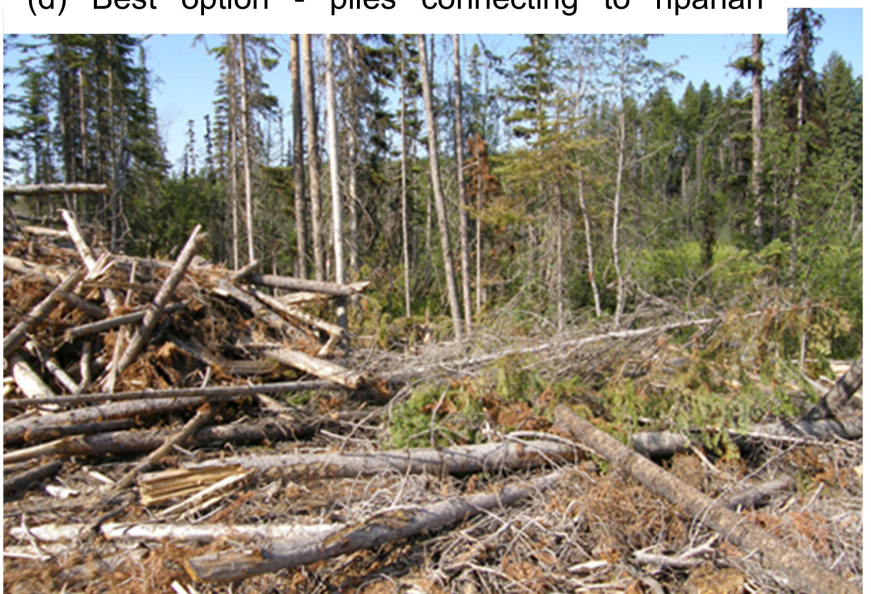

(e) Best option - piles connecting to forest

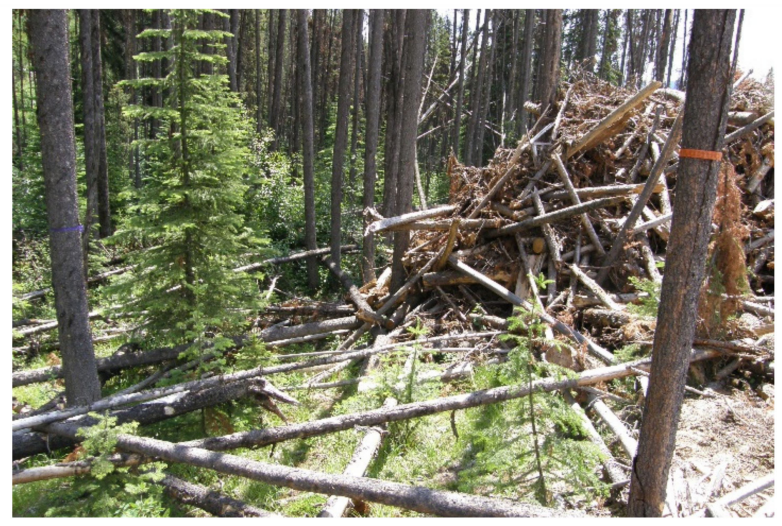

Figure 3. Options for construction of woody debris habitats: the poorest (a) minimal vertical structure to habitat; good (b) piles; better (c) linear row of piles; and best (d) piles connecting to riparian; and best (e) piles connecting to forest reserve.

\subsection{Distribution of CWD via Cut-to-Length Harvesting}

There are many harvesting systems based on forest ecosystems, topography, and region. In some instances, forests are harvested using full-tree harvesting systems where feller-bunchers cut trees and skidders move cut bunches of intact trees to landings or roadsides where they are delimbed and processed with conventional de-limbers. Cut-tolength harvested trees, often in partial cutting regimes, are processed at the tree stump in the cutblock and forwarders move the processed logs to the roadsides or landings [80]. 
Consequently, the slash accumulation of fines and tops will be higher within the cut-tolength block (Figure 4) and will likely provide a more uniform cover of postharvest debris over the harvested area. The increased woody debris loads as a consequence of cut-tolength harvesting does not significantly impede the initial growth of planted and natural regeneration of lodgepole pine if the site is treated with drag scarification [81]. Woody debris, particularly large $(>7.5 \mathrm{~cm})$ diameter logs may also be redistributed over a cutblock using grapple-skidders and excavators at the site preparation and road deactivation stages. This process provides better distribution of woody debris over a cutblock without the need to pile and dispose of debris at landings and roadsides. There may be some fire risk with fines and tops near stumps, at least until fines have decomposed, often within three years after harvest. The cost of redistribution of large woody debris from landings to the cutblock needs to be investigated.

Table 2. What to do, when, and where during the creation of habitat structures and connectivity via debris piles.

\begin{tabular}{lll}
\hline \multicolumn{1}{c}{ When } & \multicolumn{1}{c}{ Where to Place } & \multicolumn{1}{c}{ Characteristics } \\
\hline During harvesting/log processing & $\begin{array}{l}\text { Connect residual patches to each other or } \\
\text { riparian areas }\end{array}$ & $\begin{array}{l}2 \mathrm{~m} \text { in height }+5-7 \mathrm{~m} \text { in width or } \\
\text { diameter }\end{array}$ \\
\hline $\begin{array}{l}\text { Situations where biofuel production is } \\
\text { not viable }\end{array}$ & $\begin{array}{l}\text { In areas remote from human activity to } \\
\text { reduce fire risk }\end{array}$ & $\begin{array}{l}\geq 1 \text { windrow or series of piles per } 10 \text { ha of } \\
\text { cutblock }\end{array}$ \\
\hline $\begin{array}{l}\text { On sites where seedling microsites are } \\
\text { limited }\end{array}$ & $\begin{array}{l}\text { Preferably on roads perpendicular to the } \\
\text { main haul roads }\end{array}$ & $\begin{array}{l}\text { Leave openings every } 100 \mathrm{~m} \text { for } \\
\text { ungulates and silvicultural activity }\end{array}$ \\
\hline $\begin{array}{l}\text { Cutblocks }<10 \text { ha CWD should be evenly } \\
\text { distributed vs. piled }\end{array}$ & $\begin{array}{l}\text { Particularly important on } \geq 10 \text {-ha } \\
\text { openings }\end{array}$ & $\begin{array}{l}\text { On large, wide cutblocks }(>50 \mathrm{~m}) \\
\text { connectivity should include } \\
\text { patches } / \text { riparian to cross wide areas }\end{array}$ \\
\hline $\begin{array}{l}\text { Cutblocks with average distances } \\
\text { between forest edges }<50 \mathrm{~m} \text { need not } \\
\text { have piles }\end{array}$ & $\begin{array}{l}\text { In areas requiring protection from soil } \\
\text { erosion at road ways }\end{array}$ & $\begin{array}{l}\text { On irregularly shaped cutblocks use } \\
\text { narrower portions of cutblock }\end{array}$ \\
\cline { 2 - 3 } & $\begin{array}{l}\text { Avoid vole “hot-spots” due to seedling } \\
\text { predation }\end{array}$ & $\begin{array}{l}\text { Piles should be } 5 \mathrm{~m} \text { from forest or } \\
\text { riparian edges }\end{array}$ \\
\hline
\end{tabular}

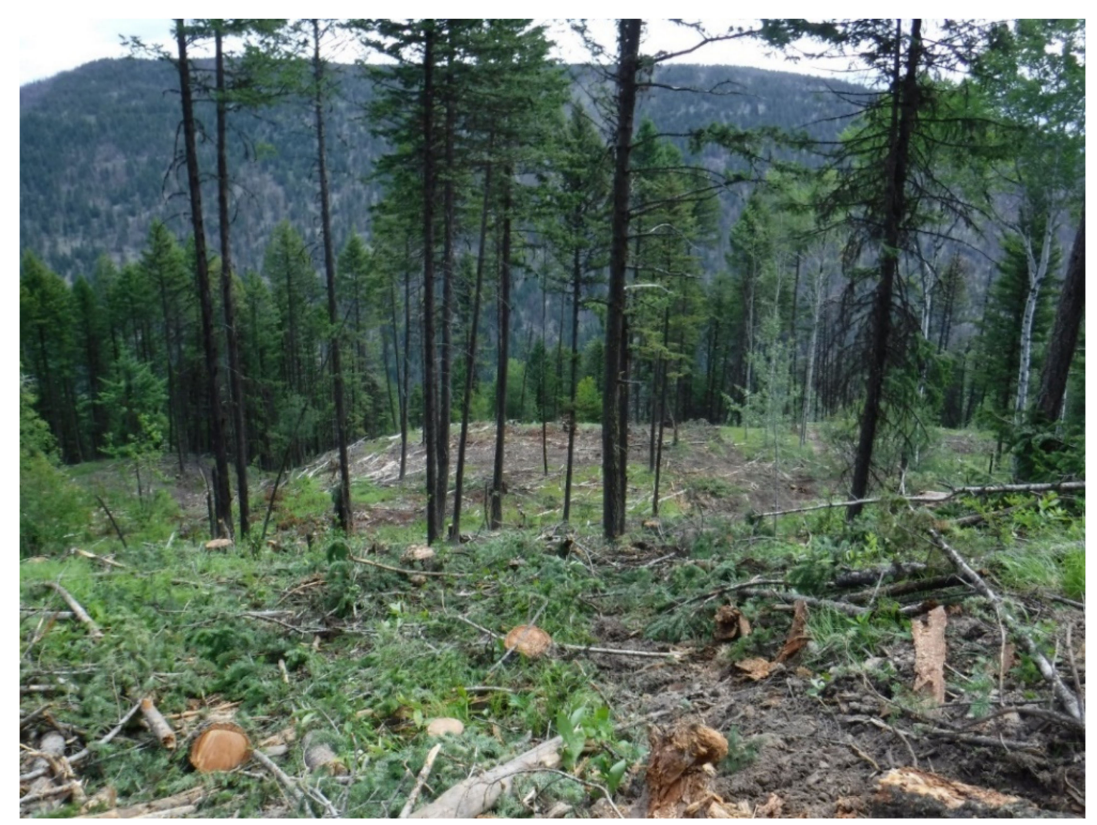

Figure 4. Partial cutting (uniform shelterwood) of Douglas-fir stand and distribution of postharvest woody debris within stand. 


\subsection{Use of Machinery to Crush Woody Debris}

There has been considerable interest in the use of mechanical mastication to address several fuel and fire management issues including the rate of spread, fire behaviour and fire intensity on low-topography ground [82-86]. Mechanical mastication of fuel beds has been used in shrub ecosystems and following harvest to address fire behaviour concerns. Mastication dramatically changes the nature of the fuel bed without reducing the overall amount of fuel. The results of numerous field trials [84] suggest mastication may reduce the rate of fire spread but can prolong fuel bed smouldering. A key aspect of mechanical, postharvest treatment of logging slash is the breaking up of fine fuels and the pressing of slash into the ground, thereby increasing soil contact and the moisture content of fuels treated in this manner (Figures 5 and 6). Under drought conditions, elevated fuels will have lower moisture content, leading to increased fire-line intensity and an increased rate of spread [83].

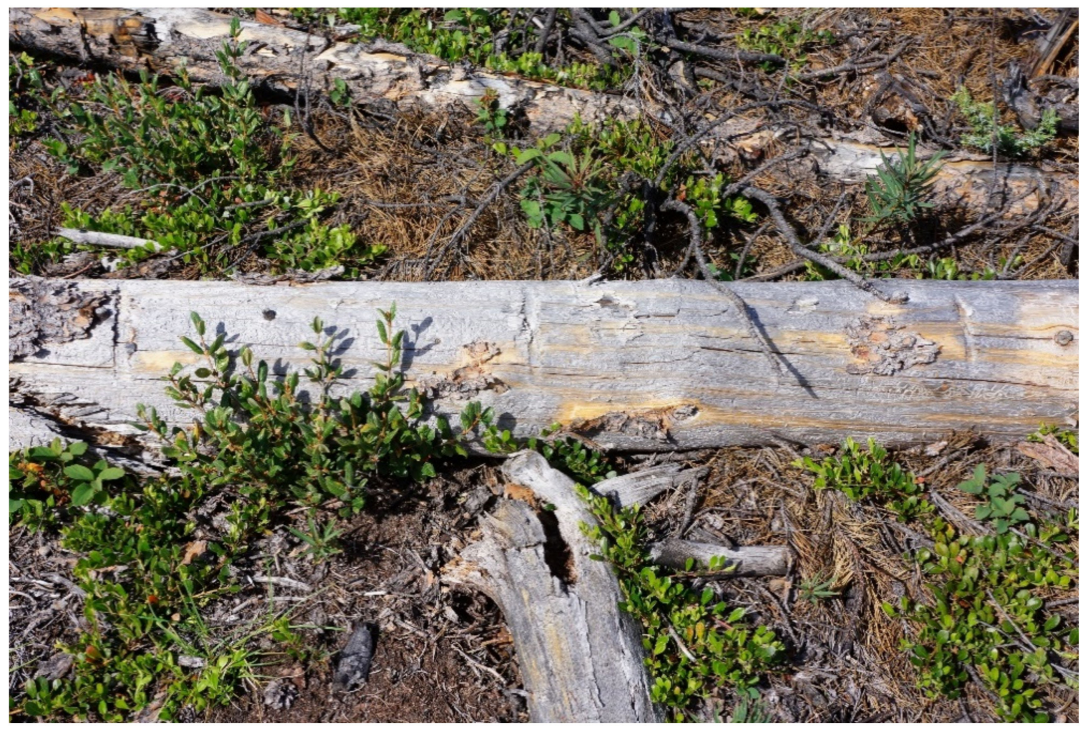

Figure 5. Postharvest material pressed into the ground with a roller-chopper mechanical treatment.

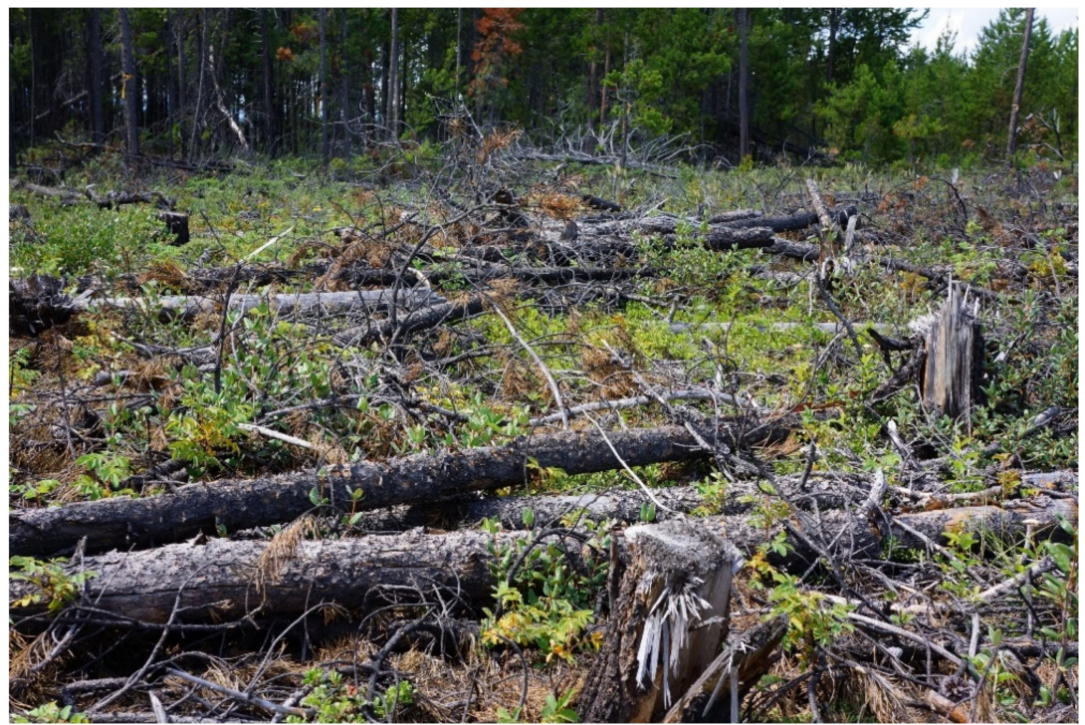

Figure 6. Untreated (elevated) slash two years after harvest.

Using various machines postharvest for site preparation and fuel management may result in small $(<7.5 \mathrm{~cm})$ material being chopped into pieces and pushed into the soil, increasing relative humidity and reducing flammability [87]. Fines (needles and small 
branches) are flattened onto the ground and larger pieces $(>7.5 \mathrm{~cm})$ are pushed onto or partially into the ground but are not chopped into small chunks. Unlike mechanical mastication, which can aerate fuels and create a relatively uniform fuel bed, heavy rollers that press logging slash into the ground (Figure 7) may hold promise but have not been widely tested for efficacy. Leaving the slash on site in this condition should increase the rate of decomposition and increase the loss rate of fine fuels on site via decomposition. In addition, this processed slash material keeps important nutrients on site for future tree growth and increases overall site productivity. Soil biota should benefit from this form of leaving nutrients and energy for decomposers and invertebrates on site. However, this process can be detrimental for saproxylic organisms that depend on intact wood, such as many species of saproxylic beetles. Different types of dead wood (size, position, moisture, sun-exposure) are used by different species [88]. In addition, some threatened species preferentially colonise intact wood over cut and damaged smaller pieces [89].

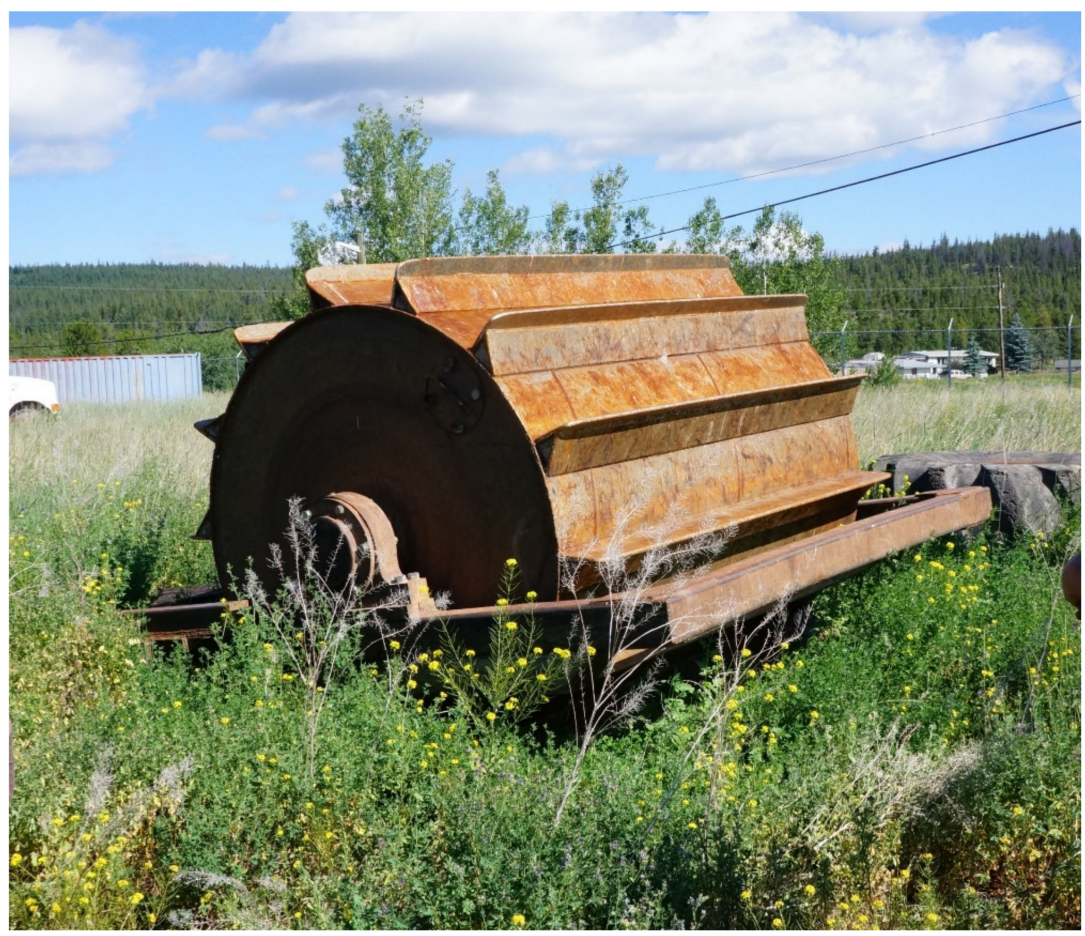

Figure 7. Example of a roller-chopper machine for treating postharvest debris.

\subsection{Protection of Riparian Zones from Cattle}

Many clearcuts have some form of riparian area within them whether they are classified as streams, wetlands, or seepage-drainage sites. In many jurisdictions there is no legislated obligation to retain a buffer zone of trees adjacent to small streams. Thus, when riparian areas are harvested or opened up due to wildfire and an overlapping grazing tenure exists, then the likelihood of riparian damage is increased. Cattle are attracted to riparian areas due to the presence of high-quality forage, water, and shade from overstory vegetation during the summer months [90]. With unimpeded access to small streams, cattle can use the stream channel as a corridor. This activity leads to trampling and widening of the stream channel, reduction in abundance and cover of vegetation, soil compaction, and addition of sediments and nutrients to the water [91,92]. However, excluding cattle from riparian areas in most grazing situations is not feasible [93].

The use of woody debris to reduce linear movements and negative effects of cattle grazing on small streams can be a cost-effective and functional means to reduce the excessive use of riparian areas by cattle [93] (Figures 8 and 9). If there are no standing trees (to be felled across the site) adjacent to a riparian area, then the need to move logs from excess debris piles to riparian sites could be done at the site preparation or road deactiva- 
tion stages. Openings in the barriers every $100 \mathrm{~m}$ or so will accommodate movement of native ungulates. An indication of similar positive results with fallen trees and branches as woody debris placement was reported for cattle in pastureland in southern Manitoba [94]. Windrows of debris placed parallel to a stream (Figures 10 and 11) are also an effective barrier for cattle $[93,95]$.

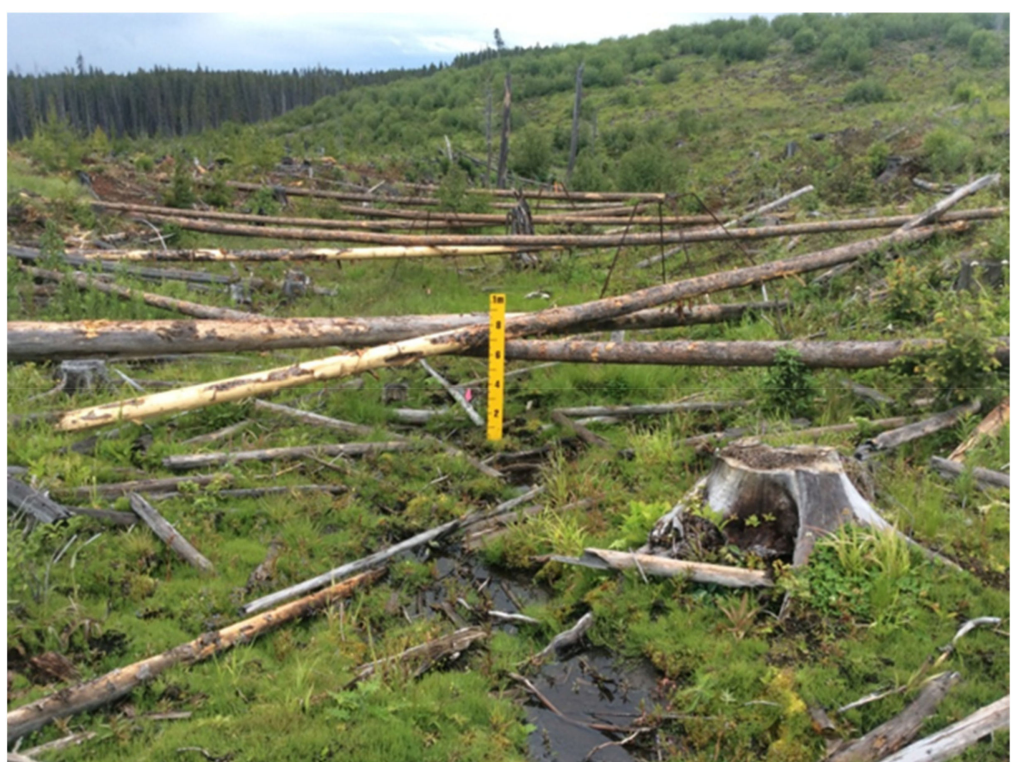

Figure 8. Cross-sectional view of log obstruction across riparian area. (Photo by C. Bradley).

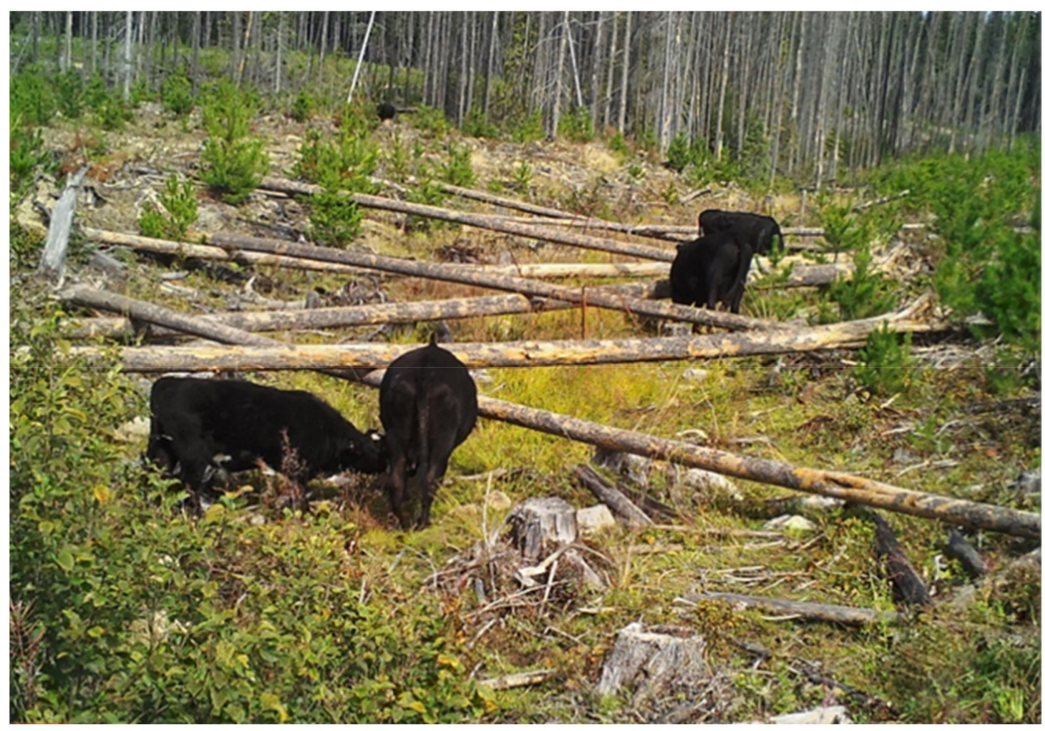

Figure 9. Cattle able to access stream for water but not move up and down channel. (Photo by C. Bradley).

\subsection{Construction of Range Fencing}

Range tenures are indicated by boundaries of standard fencing: treated wooden posts and barbed wire. An alternative method could be the use of woody debris to reduce costs, maintenance, and utilize on-site materials when new fence rights-of-way are constructed, or where nearby excess debris from harvest blocks is available. Standard gates of treated rails may be inserted within the windrow of woody debris, or logs may be used as well, to provide openings and passages for wildlife and cattle (Figures 12 and 13). 


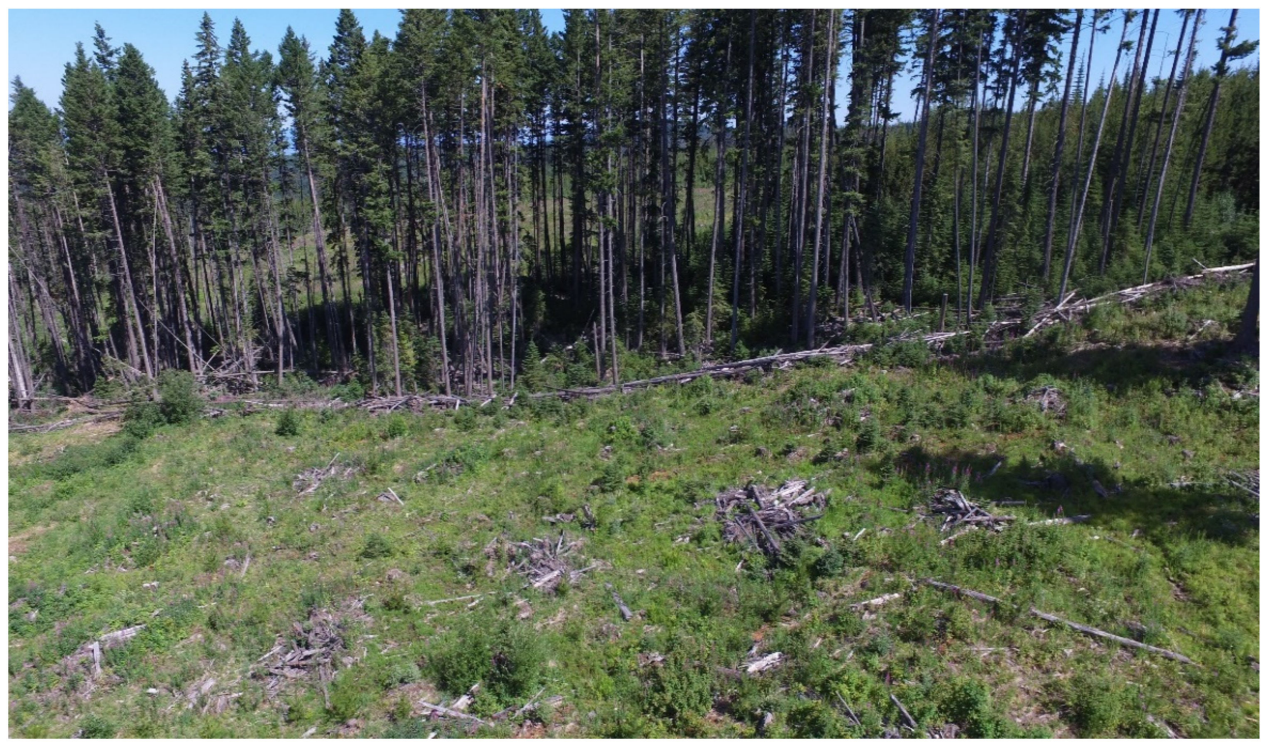

Figure 10. Linear windrow of woody debris to protect unlogged riparian area from cattle. (Photo by L. Zabek).

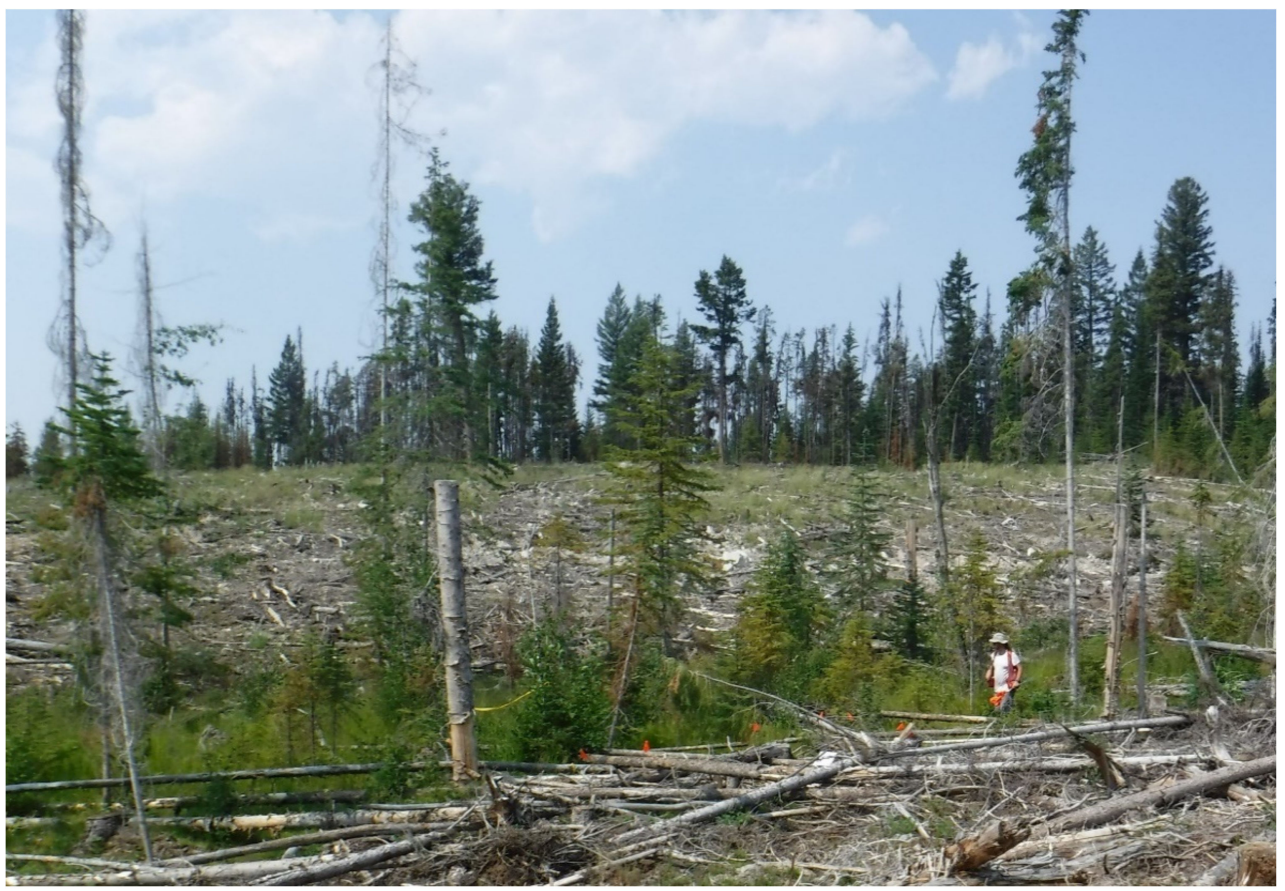

Figure 11. Linear windrow of woody debris to protect logged riparian area from cattle.

\subsection{Reclamation of Landings and Skid-Trails}

Wood mulching is not a preferred reclamation tool as it does not create microsites and depths of 3-4 cm [96] may impede plant establishment [97-99]. Ref. [100] found $>5 \mathrm{~cm}$ was required to reduce aspen sucker density with $10 \mathrm{~cm}$ causing a $50 \%$ reduction in density. On the other hand, native shrubs are capable of penetrating $7.5-\mathrm{cm}$ thick layers of wood chip treatments [101]. Chipping residues create an insulating layer thereby slowing soil warming in the spring while extending soil warmth into the fall [102]. However, chips helped keep soil cool and moist in warm regions thus aiding growing conditions for planted conifer seedlings [102]. Ref. [103] recommended that chipped material should not exceed $8 \mathrm{~cm}$ in depth for best management practices for soil conservation. Ref. [100] suggested that an application rate of $5 \mathrm{~cm}$ would provide for the replacement of nitrogen removed by harvesting. Mulch may release leachates into riparian areas, soil water [104], and adversely 
affect tree growth [105]. A study in eastern Washington found growth and survival of Douglas-fir and lodgepole pine seedlings on plots with chipped woody debris was poorer than in plots where the debris was left intact or removed [106]. Ref. [102] found improved lodgepole pine seedling survival on decompacted log landings with wood waste added to the surface or incorporated into the soil. Rough mulching or, preferably, whole logs of various diameters and lengths provide microsites with moisture, shade, and protection to plant and animal biodiversity [96].

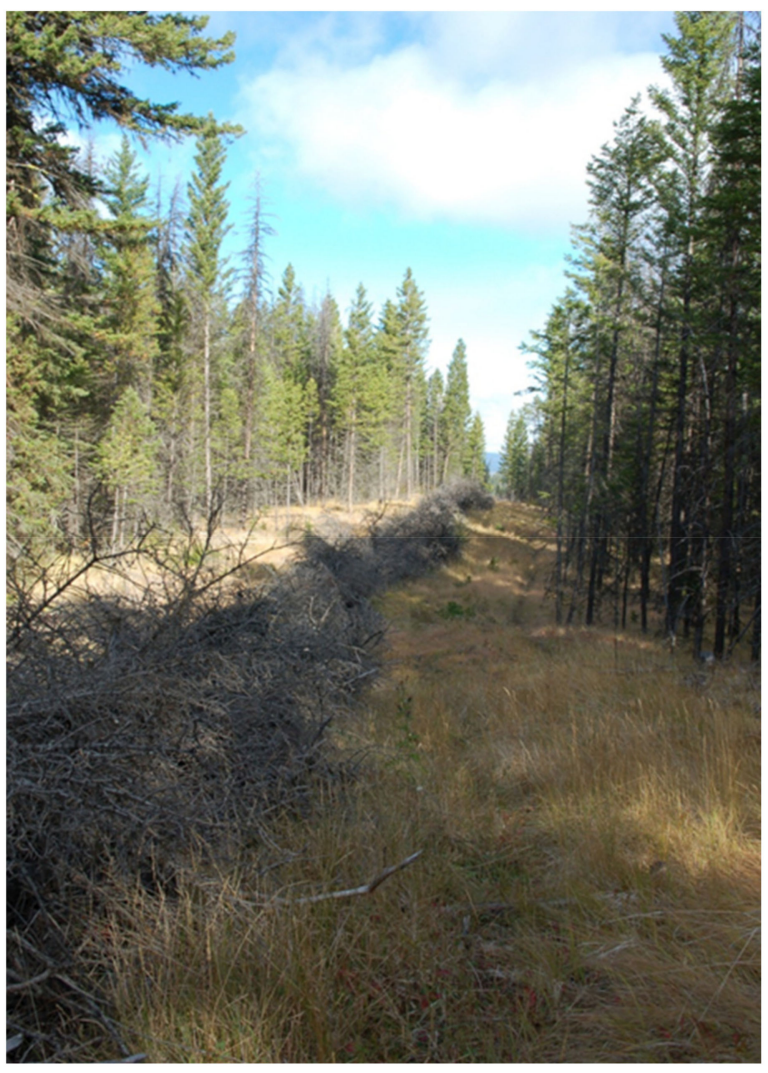

Figure 12. Length of woody debris fence. (Photo by A. Pantel).

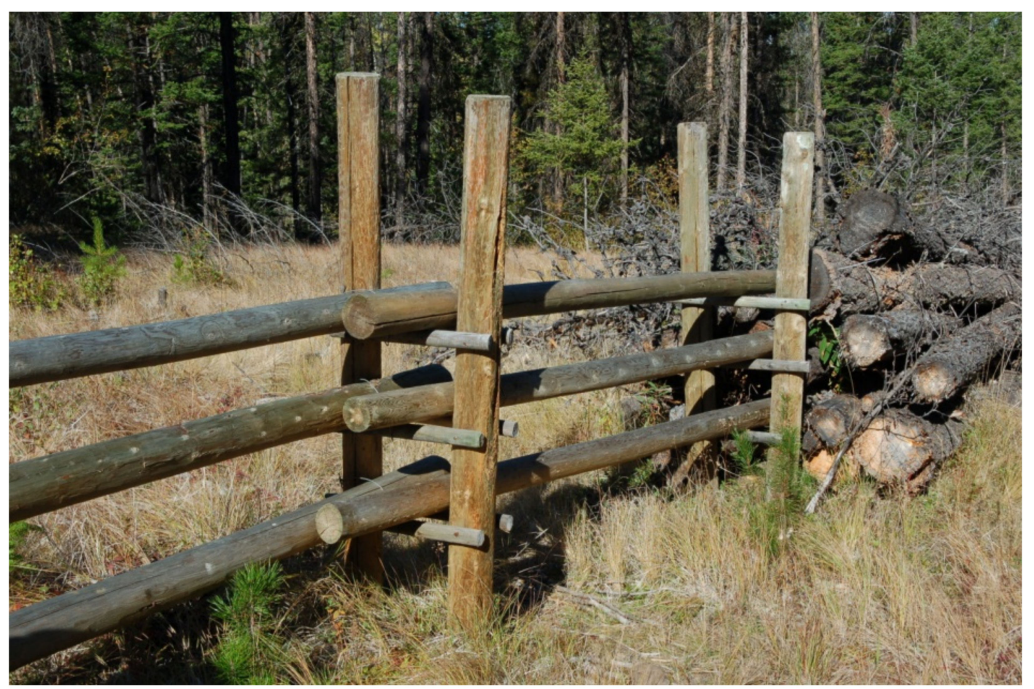

Figure 13. Wildlife/cattle gate and removable rails. (Photo by A. Pantel).

Wood mulch is useful on dry, arid soils, and does not constitute a fire hazard. Sites with whole logs provide erosion control, moisture retention, creation of microsites, heterogeneity on sites, pose a minimal fire hazard if compressed into the soil, and have improved seedling 
survival of both Douglas-fir and lodgepole pine. In terms of disadvantages, wood mulch should not be more than 3-4 cm deep, will decompose faster, thus releasing GHGs, and is more expensive than whole logs. This process may also result in the risk of leachates affecting tree growth and potentially entering riparian sites. Whole logs require moving to reclamation sites.

\subsection{Soil Fertility and Understory Plant Communities}

There have been mixed responses in soil carbon levels owing to the removal of woody debris [107]. Alternatively, there are often substantial quantities of forest residues left on site due to technical and economic factors [107]. In terms of vegetative development, [108] concluded that debris piles replace canopy gaps as sites where understory plant species can reproduce successfully, and hence are important for many plant species, their pollinators and frugivores who are dependent on them. Similarly, mulching fuels treatments promoted denser and more diverse native understory plant communities in Colorado coniferous forests [109]. Ref. [110] reported that abundant logging debris retained on clearcuts in coarse-textured soils and droughty sites in western Washington had increased forest floor mass and nutrient content and was a reduced fuel load, and hence reduced fire risk, at five years post-treatment. Abundant debris seemed to improve growing conditions for Douglas-fir and reduced the abundance of nonnative competitors [111]. This process may be a suitable treatment to assist regeneration of ponderosa pine and Douglas-fir in very dry to dry sites and could be associated with redistribution of woody debris via scarification where needed.

\subsection{Slope Stabilization and Revegetation}

Piles of woody debris appear to be a useful restoration measure on burned and logged sites with relatively steep slopes. The use of piles as erosion barriers has provided habitat for frugivorous seed-disperser birds in dry Mediterranean forests. Debris piles up to $1 \mathrm{~m}$ in height and 3-10 $\mathrm{m}$ in length along contours of hillsides showed a positive relationship between the abundance of birds and the density of the piles [112]. The taller piles showed higher values of bird-dispersed plant cover and species richness [113].

\section{Management Implications and Policy Revisions}

The management of woody debris should be part of maintaining biodiversity in commercial forest landscapes. This approach may fit into the strategy of reconciling biodiversity and carbon conservation to help mitigate the effects of climate change [114]. The research carried out in [18] concluded from a meta-analysis of CWD and biodiversity that predicting the effects of biomass harvests on forest biodiversity is uncertain until operational-scale harvests change CWD levels over relatively long time periods. However, woody debris structures clearly help maintain some mammalian aspects of forest biodiversity in the short-term. A major economic question asks: is there a monetary value lost by burning debris? This question has relevance to a forest management system (burning debris) that is exacerbating climate change and concurrently removing biomass for bioenergy production and potential habitat for wildlife, thereby compromising our attempts to conserve essential biodiversity in managed forests.

The use of excess postharvest woody debris for biofuels is, indeed, a worthwhile endeavour but is likely dependent on size of bioenergy production plant and distance between harvested sites and the plant, as well as other assumptions. Bioenergy is a renewable enterprise that results in reduced use of fossil fuels and may result in reduced carbon emissions, a widely supported environmental goal. Piles and windrows for wildlife habitat are site- and cutblock-specific connecting patches of uncut forest to forest reserves and riparian areas. They are not required on every cutblock, and generally use only $10-15 \%$ of excess postharvest woody debris.

Perhaps the most insidious part of our analysis is the negative human and environmental costs of burning piles of wood waste. Practices surrounding the use or disposal of nonsawlog wood fiber from harvested sites should be carefully examined in the context 
of the value of this material to wildlife habitat and biodiversity, the potential economic opportunities this material represents to emerging technologies, and the negative effects on human health that disposal by burning represents. To this end, a newly published United Nations report states the importance of addressing issues of climate change, biodiversity loss, and environmental pollution in a joint manner [115].

Practices that could be implemented to address these issues include:

(1) Make every effort to conserve woody debris as structures on clearcut, salvage, and burned sites;

(2) Allocate nonmerchantable sawlog wood fiber to the biofuels sector when it can be done in a cost-effective manner;

(3) Implement woody debris structures where necessary to maintain mammalian biodiversity on clearcuts, as per Table 2;

(4) Limit burning of non-sawlog wood fiber to specific locations near human activity where there is a clear potential for increased fire hazard and that do not have an opportunity for bioenergy or habitat purposes;

(5) Consider the possibilities for fate of excess postharvest woody debris and fuel hazard abatement as per Figure 14.

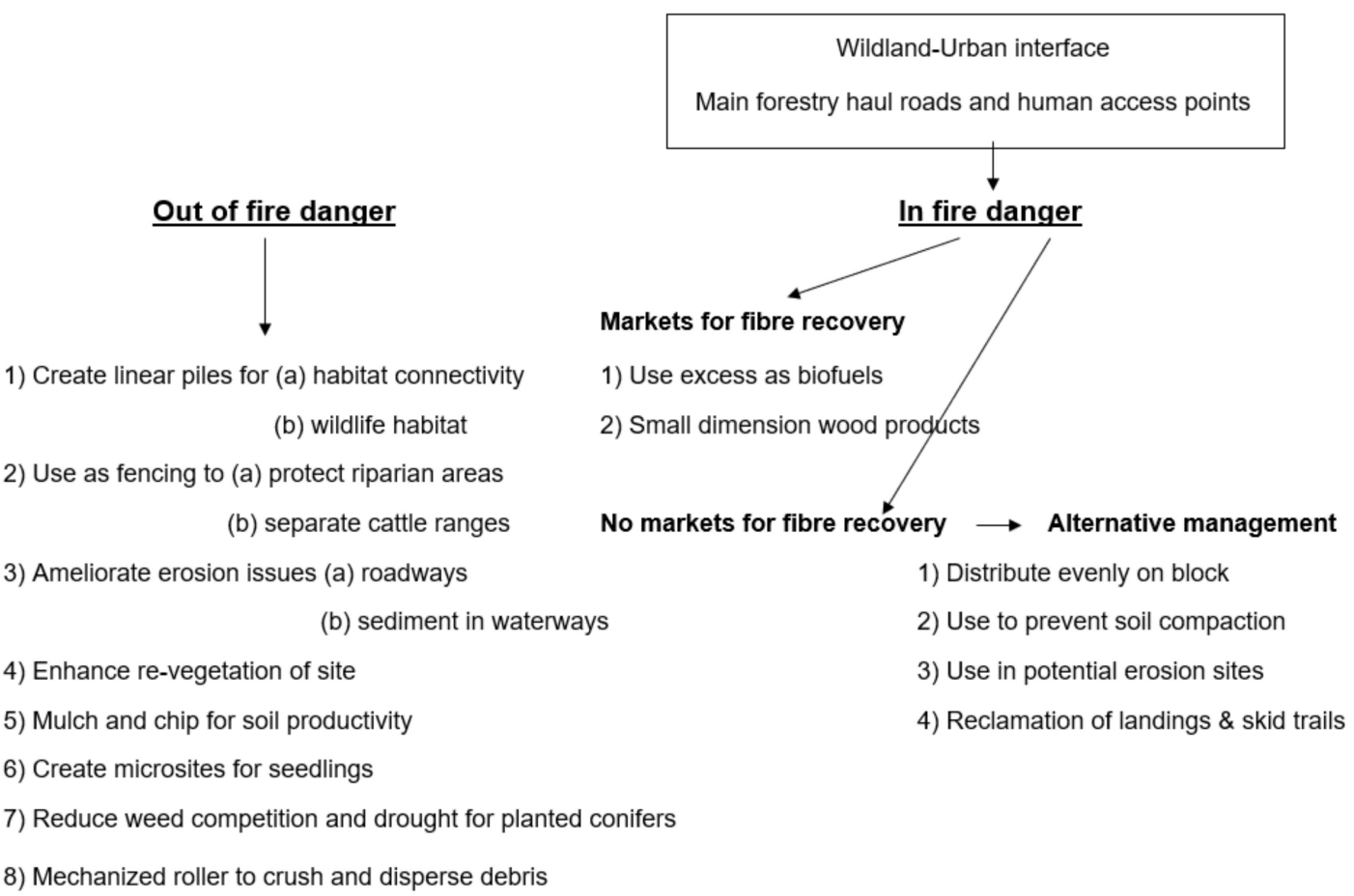

Figure 14. Flow chart for fate of excess postharvest woody debris and fuel hazard abatement.

Author Contributions: Conceptualization, T.P.S., D.S.S., W.K.; methodology, T.P.S., W.K.; formal analysis, T.P.S., D.S.S.; investigation, T.P.S., W.K.; resources, W.K.; writing-original draft, T.P.S., D.S.S.; writing-review and editing, W.K. All authors have read and agreed to the published version of the manuscript.

Funding: This research was funded by the British Columbia. Ministry of Forests, Lands, Natural Resource Operations and Rural Development, Kamloops, BC, and the Applied Mammal Research Institute.

Institutional Review Board Statement: Not applicable.

Informed Consent Statement: Not applicable.

Data Availability Statement: The data presented in the paper are available on request from the corresponding author. 
Conflicts of Interest: The authors declare no conflict of interest. The funders had no role in the design of the study; in the collection, analyses, or interpretation of data; in the writing of the manuscript, or in the decision to publish the results.

\section{References}

1. Allen, C.D.; Macalady, A.K.; Chenchouni, H.; Dominique Bachelet, N.M.; Vennetier, M.; Kitzberger, T.; Rigling, A.; Breshears, D.D.; Hogg, E.H.; Gonzalez, P.; et al. A global overview of drought and heat-induced tree mortality reveals emerging climate change risks for forests. For. Ecol. Manag. 2010, 259, 660-684. [CrossRef]

2. Lavoie, S.; Ruel, J.-C.; Bergeron, Y.; Harvey, B.D. Windthrow after group and dispersed tree retention in eastern Canada. For. Ecol. Manag. 2012, 269, 158-167. [CrossRef]

3. Cooke, B.J.; Carroll, A.L. Predicting the risk of mountain pine beetle spread to eastern pine forests: Considering uncertainty in uncertain times. For. Ecol. Manag. 2017, 396, 11-25. [CrossRef]

4. Schoennagel, T.; Balch, J.K.; Brenkert-Smith, H.; Dennison, P.E.; Harvey, B.J.; Krawchuk, P.A.; Mietkiewicz, N.; Morgan, P.; Moritz, M.A.; Rasker, R.; et al. Adapt to more wildfire in western North American forests as climate changes. Proc. Nat. Acad. Sci. USA 2017, 114, 4582-4590. [CrossRef]

5. Lindenmayer, D.B.; Franklin, J.F. Conserving Forest Biodiversity. A Comprehensive Multiscaled Approach; Island Press: Washington, DC, USA, 2002.

6. Rosenvald, R.; Lõhmus, A. For what, when, and where is green-tree retention better than clearcutting? A review of biodiversity aspects. For. Ecol. Manag. 2008, 255, 1-15. [CrossRef]

7. Lindenmayer, D.B.; Burton, P.J.; Franklin, J.F. Salvage Logging and Its Ecological Consequences; Island Press: Washington, DC, USA, 2008; p. 227.

8. Harmon, M.E.; Franklin, J.F.; Swanson, F.J.; Sollins, P.; Gregory, S.V.; Lattin, J.D.; Anderson, N.H.; Cline, S.P.; Aumen, N.G.; Sedell, J.R. Ecology of coarse woody debris in temperate ecosystems. Adv. Ecol. Res. 1986, 15, 133-302.

9. McComb, W.C.; Lindenmayer, D. Dying, dead, and down trees. In Maintaining Biodiversity in Forest Ecosystems; Hunter, M.L., Jr., Ed.; Cambridge University Press: Cambridge, UK, 1999.

10. Arsenault, A. Managing Coarse Woody Debris in British Columbia's Forests: A Cultural Shift for Professional Foresters? In Proceedings of the Symposium on the Ecology and Management of Dead Wood in Western Forests, Reno, NV, USA, 2-4 November 1999; USDA: Albany, CA, USA, 2002; pp. 869-878.

11. Hesselink, T.P. Increasing pressures to use forest biomass: A conservation viewpoint. For. Chron. 2010, 86, 28-35. [CrossRef]

12. Liu, J.C.; Pereira, G.; Uhl, S.A.; Bravo, M.A.; Bell, M.L. A systematic review of the physical health impacts from nonoccupational exposure to wildfire smoke. Environ. Res. 2015, 136, 120-132. [CrossRef]

13. Thiffault, E.; Bechard, A.; Pare, D.; Allen, D. Recovery rate of harvest residues for bioenergy in boreal and temperate forests: A review. Wiley Interdiscip. Rev. Energy Environ. 2015, 4, 429-451. [CrossRef]

14. Nurek, T.; Gendek, A.; Roman, K.; Dabrowska, M. The impact of fractional composition on the mechanical properties of agglomerated logging residues. Sustainability 2020, 12, 6120. [CrossRef]

15. Petrokofsky, G.; Hooper, O.; Petrokofsky, L.; Gant, A.E.; Harvey, W.J.; Willis, K.J. What are the impacts of the wood pellet industry on biodiversity in Southeastern USA? A systematic evidence synthesis. For. Ecol. Manag. 2021, 483, 118773. [CrossRef]

16. McComb, W.C. Ecology of Coarse Woody Debris and Its Role as Habitat for Mammals. In Mammal Community Dynamics. Management and Conservation in the Coniferous Forests of Western North America; Zabel, C.J., Anthony, R.G., Eds.; Cambridge University Press: Cambridge, UK, 2003.

17. Bunnell, F.L.; Houde, I. Down wood and biodiversity-implications to forest practices. Environ. Rev. 2010, 18, 397-421. [CrossRef]

18. Riffell, S.; Verschuyl, J.; Miller, D.; Wigley, T.B. Biofuel harvests, coarse woody debris, and biodiversity-A meta-analysis. For. Ecol. Manag. 2011, 261, 878-887. [CrossRef]

19. Fisher, J.T.; Wilkinson, L. The response of mammals to forest fire and timber harvest in the North American boreal forest. Mamm. Rev. 2005, 35, 51-81.

20. Hargis, C.D.; Bissonette, J.A.; Turner, D.L. The influence of forest fragmentation and landscape pattern on American martens. J. Appl. Ecol. 1999, 36, 157-172. [CrossRef]

21. Buskirk, S.W.; Zielinski, W.J. Small and mid-sized carnivores. In Mammal Community Dynamics. Management and Conservation in the Coniferous Forests of Western North America; Zabel, C.J., Anthony, R.G., Eds.; Cambridge University Press: Cambridge, UK, 2003; pp. 207-249.

22. Lavoie, M.; Renard, A.; Lariviere, S. Timber harvest jeopardize marten persistence in the heart of its range. For. Ecol. Manag. 2019, 442, 46-52. [CrossRef]

23. Martin, S.K. Feeding ecology of American martens and fishers. In Martens, Sables, and Fishers. Biology and Conservation; Buskirk, S.W., Harestad, A.S., Raphael, M.G., Powell, R.A., Eds.; Cornell University Press: Ithaca, NY, USA; London, UK, 1994; pp. 297-315.

24. Zwolak, R. A meta-analysis of the effects of wildfire, clearcutting, and partial harvest on the abundance of North American small mammals. For. Ecol. Manag. 2009, 258, 539-545. [CrossRef] 
25. Homyack, J.A.; Verschuyl, J. Effects of harvesting forest-based biomass on terrestrial wildlife. In Renewable Energy and Wildlife Conservation; Moorman, C.E., Grodsky, S.M., Rupp, S.P., Eds.; Johns Hopkins University Press: Baltimore, MD, USA, 2019; pp. 22-40.

26. Seibold, S.; Bassler, C.; Brandl, R.; Gossner, M.M.; Thorn, S.; Ulyshen, M.D.; Muller, J. Experimental studies of dead-wood biodiversity-A review identifying global gaps in knowledge. Biol. Conserv. 2015, 191, 139-149. [CrossRef]

27. Sullivan, T.P.; Sullivan, D.S.; Lindgren, P.M.F.; Ransome, D.B.; Bull, J.G.; Ristea, C. Bioenergy or biodiversity: Woody debris structures and maintenance of red-backed voles on clearcuts. Biomass Bioenergy 2011, 35, 4390-4398. [CrossRef]

28. Sullivan, T.P.; Sullivan, D.S.; Lindgren, P.M.F.; Ransome, D.B. If we build habitat, will they come? Woody debris structures and conservation of forest mammals. J. Mammal. 2012, 93, 1456-1468. [CrossRef]

29. Sullivan, T.P.; Sullivan, D.S.; Sullivan, J.H. Mammalian responses to windrows of woody debris on clearcuts: Abundance and diversity of forest-floor small mammals and presence of small mustelids. For. Ecol. Manag. 2017, 399, 143-154. [CrossRef]

30. British Columbia Forest Safety Council. Forest Safety News. 1, 4. Forest Safety, Nanaimo, BC, Canada, 2014. Available online: https:/ / selkirk.ca/sites/default/files/Workplace\%20Training/Delia\%20Roberts/BCForestSafetyNewsletter_2014April. pdf (accessed on 25 April 2021).

31. Natural Resources Canada, 2016. Available online: www.nrcan.gc.ca/forests (accessed on 15 March 2018).

32. Baxter, G. The Fire History of Slash Fuels in Alberta for the Period 1961-2000; FERIC: Hinton, AB, Canada, $2002 ;$ p. 22.

33. Martinson, E.J.; Omi, P.N. Fuel Treatment and Fire Severity: A Meta-Analysis; Rocky Mountain Research Station: Ft. Collins, CO, USA, 2013.

34. Cook, P.S.; O'Laughlin, J. Fuel Treatments in Idaho's Forests: Effectiveness, Constraints, and Opportunities; Policy Analysis Group, College of Natural Resources, University of Idaho: Moscow, ID, USA, 2014.

35. Miller, C.; Urban, D.L. Connectivity of forest fuels and surface fire regimes. Landsc. Ecol. 2000, 15, 145-154. [CrossRef]

36. Schoennagel, T.; Veblen, T.T.; Romme, W.H. The interaction of fire, fuels, and climate across rocky mountain forests. BioScience 2004, 54, 661-676. [CrossRef]

37. Barkley, Y.C.; Schnepf, C.; Cohen, J.D. Protecting and Landscaping Homes in the Wildland/Urban Interface; Idaho Forest, Wildlife and Range Experiment Station: Moscow, ID, USA, 2010.

38. Brown, J.K.; Reinhardt, E.D.; Kramer, K.A. Coarse Woody Debris: Managing Benefits and Fire Hazard in the Recovering Forest; USDA Rocky Mountain Research Station: Ogden, UT, USA, 2003.

39. Schroeder, D.; Russo, G.; Beck, J.; Hawkes, B.; Dalrymple, G. Modeling ignition probability of thinned lodgepole pine stands. Forest Engineering Research Institute Canada, Vancouver, B.C. Advantage 2006, 7, 8.

40. Schroeder, D. Fire behaviour in thinned jack pine: Two case studies of FireSmart treatments in Canada's Northwest Territories. FPInnovations FERIC. Advantage 2010, 12, 12.

41. Sullivan, A.L.; Surawski, N.C.; Crawford, D.; Hurley, R.J.; Volkova, L.; Weston, C.J. Effect of woody debris on the rate of spread of surface fires in forest fuels in a combustion wind tunnel. For. Ecol. Manag. 2018, 424, 235-245. [CrossRef]

42. Cascio, W.E. Wildland fire smoke and human health. Sci. Total Environ. 2018, 624, 586-595. [CrossRef]

43. Ritz, B.; Fei, Y.; Fruin, S.; Chapa, G.; Shaw, G.M.; Harris, J.A. Ambient air pollution and risk of birth defects in southern California. Am. J. Epidemiol. 2002, 155, 17-25. [CrossRef]

44. Tan, W.C.; Qiu, D.; Liam, B.L.; Ng, T.P.; Lee, S.H.; van Eeden, S.F.; D’Yachkova, Y.; Hogg, J.C. The human bone marrow response to acute air pollution caused by forest fires. Am. J. Respir. Crit. Care Med. 2000, 161, 1213-1217. [CrossRef]

45. Sutherland, E.R.; Make, B.J.; Vedal, S.; Zhang, L.; Dutton, S.J.; Murphy, J.R.; Silkoff, P.E. Wildfire smoke and respiratory symptoms in patients with chronic obstructive pulmonary disease. J. Allergy Clin. Immunol. 2005, 115, 420-422. [CrossRef]

46. Crabbe, H. Risk of respiratory and cardiovascular hospitalization with exposure to bushfire particulates: New evidence from Darwin, Australia. Environ. Geochem. Health 2012, 34, 697-709. [CrossRef] [PubMed]

47. Aditama, T.Y. Impact of haze from forest fire to respiratory health: Indonesian experience. Respirology 2000, 5, 169-174. [CrossRef] [PubMed]

48. Naeher, L.P.; Brauer, M.; Lipsett, M.; Zelikoff, J.T.; Simpson, C.D.; Koenig, J.Q. Woodsmoke health effects: A review. Inhal. Toxicol. 2007, 19, 67-106. [CrossRef] [PubMed]

49. Kumar, A. A conceptual comparison of bioenergy options for using mountain pine beetle infested wood in western Canada. Bioresour. Technol. 2009, 100, 387-399. [CrossRef]

50. Mabee, W.E.; Saddler, J.N. Bioethanol from lignocellulosics: Status and perspectives in Canada. Bioresource Technology 2009, 101, 4806-4813. [CrossRef]

51. Magelli, F.; Boucher, K.; Hsiaotao, T.B.; Melin, S.; Bonoli, A. An environmental impact assessment of exported wood pellets from Canada to Europe. Biomass Bioenergy 2009, 33, 434-441. [CrossRef]

52. WPAC Wood Pellet Association of Canada. Canadian Pellet Industry Update. PFI Annual Conference, Williamsburg, VA. WPAC Website; 2015. Available online: https://www.pellet.org/images/pellet/PFI-AGM.pdf (accessed on 25 April 2021).

53. Laganiere, J.; Pare, D.; Thiffault, E.; Bernier, P.Y. Range and uncertainties in estimating delays in greenhouse gas mitigation potential of forest bioenergy sourced from Canadian forests. Glob. Change Biol. Bioenergy 2017, 9, 358-369. [CrossRef]

54. Moses, R.A.; Boutin, S. The influence of clear-cut logging and residual leave material on small mammal populations in aspendominated boreal mixedwoods. Can. J. For. Res. 2001, 31, 483-495. [CrossRef] 
55. Lisgo, K.A.; Bunnell, F.L.; Harestad, A.S. Summer and Fall Use of Logging Residue Piles by Female Short-Tailed Weasels. In Proceedings of the Symposium on the Ecology and Management of Dead Wood in Western Forests, Reno, NV, USA, 2-4 November 1999; USDA: Albany, CA, USA, 2002; pp. 319-329.

56. Craig, V.J.; Klenner, W.; Feller, M.C.; Sullivan, T.P. Relationships between deer mice (Peromyscus maniculatus) and downed wood in managed forests of southern British Columbia. Can. J. For. Res. 2006, 36, 2189-2203. [CrossRef]

57. Manning, J.A.; Edge, W.D. Small mammal responses to fine woody debris and forest fuel reduction in southwest Oregon. J. Wildl. Manag. 2008, 72, 625-632. [CrossRef]

58. Moseley, K.R.; Owens, A.K.; Castleberry, S.B.; Ford, W.M.; Kilgo, J.C.; McCay, T.S. Soricid response to coarse woody debris manipulations in Coastal Plain loblolly pine forests. For. Ecol. Manag. 2008, 255, 2306-2311. [CrossRef]

59. Davis, J.C.; Castleberry, S.B.; Kilgo, J.C. Influence of coarse woody debris on the soricid community in southeastern Coastal Plain pine stands. J. Mamm. 2010, 91, 993-999. [CrossRef]

60. Fauteux, D.; Imbeau, L.; Drapeau, P.; Mazerolle, M.J. Small mammal responses to coarse woody debris distribution at different spatial scales in managed and unmanaged boreal forests. For. Ecol. Manag. 2012, 266, 194-205. [CrossRef]

61. Sullivan, T.P.; Sullivan, D.S. Woody debris, voles, and trees: Influence of habitat structure (piles and windrows) on long-tailed vole populations and feeding damage. For. Ecol. Manag. 2012, 263, 189-198. [CrossRef]

62. Sullivan, T.P.; Sullivan, D.S. Diversifying clearcuts with green-tree retention and woody debris structures: Conservation of mammals across forest ecological zones. Silva Fenn. 2014, 48, 1219. [CrossRef]

63. Craig, V.J.; Klenner, W.; Feller, M.C.; Sullivan, T.P. Population dynamics of red-backed voles (Myodes gapperi) and their relationship to downed wood in managed forests of southern British Columbia. Can. Wildl. Biol. Manag. 2014, 3, 93-108.

64. Craig, V.J.; Klenner, W.; Feller, M.C.; Sullivan, T.P. Population dynamics of meadow voles (Microtus pennsylvanicus) and long-tailed voles (M. longicaudus) and their relationship to downed wood in managed forests. Mam. Res. 2015, 60, 29-38. [CrossRef]

65. Fritts, S.R.; Moorman, C.E.; Grodsky, S.M.; Hazel, D.W.; Homyack, J.A.; Farrell, C.B.; Castleberry, S.B. Shrew response to variable woody debris retention: Implications for sustainable forest bioenergy. For. Ecol. Manag. 2015, 336, 35-43. [CrossRef]

66. Goguen, C.B.; Fritsky, R.S.; San Julian, G.J. Effects of brush piles on small mammal abundance and survival in central Pennsylvania. J. Fish Wildl. Manag. 2015, 6, 392-404. [CrossRef]

67. Fritts, S.R.; Moorman, C.E.; Grodsky, S.M.; Hazel, D.W.; Homyack, J.A.; Farrell, C.B.; Castleberry, S.B.; Evans, E.H.; Greene, D.U. Rodent response to harvesting woody biomass for bioenergy production. J. Wildl. Manag. 2017, 81, 1170-1178. [CrossRef]

68. Sullivan, T.P.; Sullivan, D.S. Maintenance of small mammals using post-harvest woody debris structures on clearcuts: Linear configuration of piles is comparable to windrows. Mammal Res. 2018, 63, 11-19. [CrossRef]

69. Seip, C.; Hodder, D.; Crowley, S.; Johnson, C. Use of constructed coarse woody debris corridors in a clearcut by American martens (Martes americana) and their prey. Forestry 2018, 91, 506-513. [CrossRef]

70. Sullivan, T.P.; Sullivan, D.S. Long-term functionality of woody debris structures for forest-floor small mammals on clearcuts. For. Ecol. Manag. 2019, 451, 117535. [CrossRef]

71. Loeb, S.C. Responses of small mammals to coarse woody debris in a Southeastern pine forest. J. Mamm. 1999, 80, 460-471. [CrossRef]

72. Steel, E.A.; Naiman, R.J.; West, S.D. Use of woody debris piles by birds and small mammals in a riparian corridor. Northwest Sci. 1999, 73, 19-26.

73. McCay, T.S.; Komoroski, M.J. Demographic responses of shrews to removal of coarse woody debris in a managed pine forest. For. Ecol. Manag. 2004, 189, 387-395. [CrossRef]

74. Waldien, D.L.; Hayes, J.P.; Huso, M.P.P. Use of downed wood by Townsend's chipmunks (Tamias townsendii) in western Oregon. J. Mammal. 2006, 87, 454-460. [CrossRef]

75. Gustafsson, L.; Baker, S.C.; Bauhus, J.; Beese, W.J.; Brodie, A.; Kouki, J.; Lindenmayer, D.B.; Lohmus, A.; Pastur, G.M.; Messier, C.; et al. Retention forestry to maintain multifunctional forests: A world perspective. BioScience 2012, 62, 633-645. [CrossRef]

76. Ecke, F.; Löfgren, O.; Hörnfeldt, B.; Ekelund, U.; Ericsson, P.; Sörlin, D. Abundance and diversity of small mammals in relation to structural habitat factors. Ecol. Bull. 2001, 49, 165-171.

77. Ecke, F.; Löfgren, O.; Sörlin, D. Population dynamics of small mammals in relation to forest age and structural habitat factors in northern Sweden. J. Appl. Ecol. 2002, 39, 781-792. [CrossRef]

78. Siitonen, J. Forest management, coarse woody debris and saproxylic organisms: Fennoscandian boreal forests as an example. Ecol. Bull. 2001, 49, 11-41.

79. Bogdziewicz, M.; Zwolak, R. Responses of small mammals to clear-cutting in temperate and boreal forests of Europe: A meta-analysis and review. Eur. J. For. Res. 2014, 133, 1-11. [CrossRef]

80. McInnis, B.G.; Roberts, M.R. Seedling microenvironment in full-tree and tree length logging slash. Can. J. For. Res. 1995, 25, 128-136. [CrossRef]

81. Landhäusser, S.M. Impact of slash removal, drag scarification, and mounding on lodgepole pine cone distribution and seedling regeneration after cut-to-length harvesting on high elevation sites. For. Ecol. Manag. 2009, 258, 43-49. [CrossRef]

82. Knapp, E.E.; Varner, J.M.; Busse, M.D.; Skinner, C.N.; Shestak, C.J. Behaviour and effects of prescribed fire in masticated fuelbeds. Int. J. Wildland Fire 2011, 20, 932-945. [CrossRef]

83. Kreye, J.K.; Kobziar, L.N.; Zipperer, W.C. Effects of fuel load and moisture content on fire behaviour and heating in masticated litter-dominated fuels. Int. J. Wildland Fire 2012, 22, 440-445. [CrossRef] 
84. Kreye, J.K.; Brewer, N.W.; Morgan, P.; Varner, J.M.; Smith, A.M.S.; Hoffman, C.M.; Ottmar, R.D. Fire behaviour in masticated fuels: A review. For. Ecol. Manag. 2014, 314, 193-207. [CrossRef]

85. Brennan, T.J.; Keeley, J.E. Effect of mastication and other mechanical treatments on fuel structure in chaparral. Int. J. Wildland Fire 2015. [CrossRef]

86. Moore, B.; Thompson, D.K.; Schroeder, D.; Hvenegaard, S. Using infared imagery to assess fire behaviour in a mulched fuel bed in black spruce forests. Fire 2020, 3, 37. [CrossRef]

87. Amacher, A.J.; Barrett, R.H.; Moghaddas, J.J.; Stephens, S.L. Preliminary effects of fire and mechanical fuel treatments on the abundance of small mammals in the mixed-conifer forest of the Sierra Nevada. For. Eco. Manag. 2008, 255, 3193-3202. [CrossRef]

88. Jonsell, M.; Weslien, J.; Ehnstrom, B. Substrate requirements of red-listed saproxylic invertebrates in Sweden. Biodiv. Conserv. 1998, 7, 749-764. [CrossRef]

89. Rubene, D.; Wikars, L.-O.; Ranius, T. Importance of high-quality early-successional habitats in managed forest landscapes to rare beetle species. Biodiv. Conserv. 2014, 23, 449-466. [CrossRef]

90. Kauffman, J.B.; Krueger, W.C. Livestock impacts on riparian ecosystems and streamside management implications. A review. J. Range Manag. 1984, 37, 430-438. [CrossRef]

91. Bock, C.E.; Bock, J.H.; Smith, H.M. Proposal for a system of federal livestock exclosures on public rangelands in the western United States. Conserv. Biol. 1993, 7, 731-733. [CrossRef]

92. Fleischner, T.L. Ecological costs of livestock grazing in western North America. Conserv. Biol. 1994, 8, 629-644. [CrossRef]

93. Bradley, C. Reducing the Cumulative Effect of Timber Harvest and Livestock Grazing Using Debris Barriers. Master's Thesis, Thompson Rivers University, Kamloops, BC, Canada, 2020.

94. Rawluk, A.A.; Crow, G.; Legesse, G.; Veira, D.M.; Bullock, P.R.; Gonzalez, L.A.; Dubois, M.; Ominski, K.H. Off-stream watering systems and partial barriers as a strategy to maximize cattle production and minimize time spent in the riparian area. Animals 2014, 4, 670-692. [CrossRef]

95. Thevathasan, N.V. Agroforestry in Canada and its role in farming systems. In Temperate Agroforestry Systems, 2nd ed.; Gordon, A.M., Newman, S.M., Coleman, B., Eds.; CABI: Wallingford, UK, 2017.

96. Vinge, T.; Pyper, M. Managing Woody Materials on Industrial Sites: Meeting Economic, Ecological, and Forest Health Goals through a Collaborative Approach; University of Alberta: Edmonton, AB, USA, 2012; p. 32.

97. Landhäusser, S.M.; Lieffers, V.J.; Chow, P. Impact of chipping residues and their leachate on the initiation and growth of aspen root suckers. Can. J. Soil Sci. 2007, 87, 361-367. [CrossRef]

98. Law, D.J.; Kolb, P.F. The effects of forest residual debris disposal on perennial grass emergence, growth, and survival in a ponderosa pine ecotone. Range. Ecol. Manag. 2007, 60, 632-643. [CrossRef]

99. Wolk, B.; Rocca, M.E. Thinning and chipping small-diameter ponderosa pine changes understory plant communities on the Colorado Front Range. For. Ecol. Manag. 2009, 257, 85-95. [CrossRef]

100. Corns, G.W.; Maynard, D.G. Effects of soil compaction and chipped aspen residue on aspen regeneration and soil nutrients. Can J. Soil Sci. 1998, 78, 85-92. [CrossRef]

101. Miller, E.M.; Seastedt, T.R. Impacts of woodchip amendments and soil nutrient availability on understory vegetation establishment following thinning of a ponderosa pine forest. For. Ecol. Manag. 2009, 258, 263-272. [CrossRef]

102. Bulmer, C.; Venner, K.; Prescott, C. Forest soil rehabilitation with tillage and wood waste enhances seedling establishment but not height after 8 years. Can. J. For. Res. 2007, 37, 1894-1906. [CrossRef]

103. Kabzems, R.; Dube, S.; Curran, M.; Chapman, B.; Berch, S.; Hope, G.; Kranabetter, M.; Bulmer, C. Maintaining Soil Productivity in Forest Biomass Chipping Operations Best Management Practices for Soil Conservation; Extension Note \#98; BC Ministry of Forests and Range Forest Science Program: Victoria, BC, Canada, 2011.

104. Hart, G.E.; DeByle, N.V.; Hennes, R.W. Slash treatment after clearcutting lodgepole pine affects nutrients in soil water. J. For. 1981, $79,446-450$.

105. Conlin, T.S.S. In-woods chipping: Possible evidence for allelochemical interaction of leachate generated from trembling aspen (Populus tremuloides Michx.) bark and wood waste. For. Chron. 2001, 77, 345-349. [CrossRef]

106. Zabowski, D.; Java, B.; Scherer, G.; Everett, R.L.; Ottmar, R. Timber harvesting residue treatment: Part 1. Responses of conifer seedlings, soils and microclimate. For. Ecol. Manag. 2000, 126, 25-34. [CrossRef]

107. Vance, E.D. Conclusions and caveats from studies of managed forest carbon budgets. For. Ecol. Manag. 2018, 427, 350-354. [CrossRef]

108. McCavour, M.J.; Pare, D.; Messier, C.; Thiffault, N.; Thiffault, E. The role of aggregated forest harvest residue in soil fertility, plant growth, and pollination services. Soil Sci. Soc. Amer. J. 2014. [CrossRef]

109. Fornwalt, P.J.; Rocca, M.E.; Battaglia, M.A.; Rhoades, C.C.; Ryan, M.G. Mulching fuels treatments promote understory plant communities in three Colorado, USA, coniferous forest types. For. Ecol. Manag. 2017, 385, 214-224. [CrossRef]

110. Harrington, T.B.; Peter, D.H.; Slesak, R.A. Logging debris and herbicide treatments improve growing conditions for planted Douglas-fir on a droughty forest site invaded by Scotch broom. For. Ecol. Manag. 2018, 417, 31-39. [CrossRef]

111. Peter, D.H.; Harrington, T.B. Effects of forest harvesting, logging debris, and herbicides on the composition, diversity and assembly of a western Washington, USA plant community. For. Ecol. Manag. 2018, 417, 18-30. [CrossRef]

112. Rost, J.; Clavero, M.; Bas, J.M.; Pons, P. Building wood debris piles benefits avian seed dispersers in burned and logged Mediterranean pine forests. For Ecol manag. 2010, 260, 79-86. [CrossRef] 
113. Rost, J.; Bas, J.M.; Pons, P. The importance of piled wood debris on the distribution of bird-dispersed plants in burned and logged Mediterranean pine forests. Int. J. Wildland Fire 2011, 21, 79-85. [CrossRef]

114. Thomas, C.D.; Anderson, B.J.; Moilanen, A.; Eigenbrod, F.; Heinemeyer, A.; Quaife, T.; Roy, D.B.; Gillings, S.; Armsworth, P.R.; Gaston, K.J. Reconciling biodiversity and carbon conservation. Ecol. Lett. 2013, 16, 39-47. [CrossRef] [PubMed]

115. United Nations Environment Programme. Making Peace with Nature. 2021. Available online: https://news.un.org/en/story/2021 /02/1085092 (accessed on 15 January 2001). 